Review

\title{
Shifting Perspectives of Translational Research in Bio-Bactericides: Reviewing the Bacillus amyloliquefaciens Paradigm
}

\author{
Anastasia Dimopoulou ${ }^{1}$, Ioannis Theologidis ${ }^{2}{ }^{-}$, Adamantia Varympopi ${ }^{3}$, Dimitris Papafotis ${ }^{3}$, \\ Glykeria Mermigka ${ }^{1}$, Aliki Tzima ${ }^{4}$, Nick J. Panopoulos ${ }^{5}$ and Nicholas Skandalis ${ }^{6, *(1)}$
}

1 Institute of Molecular Biology and Biotechnology, FORTH, 70013 Heraklion, Greece; anastasia_dimopoulou@imbb.forth.gr (A.D.); glykeria_mermigka@imbb.forth.gr (G.M.)

2 Laboratory of Pesticides' Toxicology, Benaki Phytopathological Institute, 14561 Athens, Greece; i.theologidis@bpi.gr

3 Enzyme and Microbial Biotechnology Unit, Department of Biology, National and Kapodistrian University of Athens, 15784 Athens, Greece; avarympopi@biol.uoa.gr (A.V.); dpapafotis@biol.uoa.gr (D.P.)

4 Laboratory of Plant Pathology, Department of Crop Production, School of Agricultural Production Infrastructure and Environment, Faculty of Crop Science, Agricultural University of Athens, 11855 Athens, Greece; aliki@aua.gr

5 Department of Environmental Science, Policy and Management, University of California, Berkeley, CA 94720, USA; npanopoul@gmail.com

check for updates

Citation: Dimopoulou, A.; Theologidis, I.; Varympopi, A.; Papafotis, D.; Mermigka, G.; Tzima, A.; Panopoulos, N.J.; Skandalis, N. Shifting Perspectives of Translational Research in Bio-Bactericides: Reviewing the Bacillus amyloliquefaciens Paradigm. Biology 2021, 10, 1202. https://doi.org/ 10.3390/biology10111202

Academic Editor: Xuehong Zhang

Received: 24 September 2021

Accepted: 15 November 2021

Published: 18 November 2021

Publisher's Note: MDPI stays neutral with regard to jurisdictional claims in published maps and institutional affiliations.

Copyright: (c) 2021 by the authors. Licensee MDPI, Basel, Switzerland. This article is an open access article distributed under the terms and conditions of the Creative Commons Attribution (CC BY) license (https:// creativecommons.org/licenses/by/ $4.0 /)$.
6 Health Sciences Campus, Keck School of Medicine, University of Southern California, 1441 Eastlake Ave, Los Angeles, CA 90033, USA

* Correspondence: skandali@usc.edu

Simple Summary: The continuous reduction of approved conventional microbicides, due to health concerns and the development of plant-pathogen resistance, has been urged for the use of safe alternatives in crop protection. Several beneficial bacterial species, termed biological control agents, are currently used in lieu of chemical pesticides. The approach to select such bacterial species and manufacture commercial products has been based on their biocontrol effect under optimal growth conditions, which is far from the real nutrient-limited field conditions of plant niches. It's important to determine the complex interactions that occur among BCAs, plant host and niche microbiome to fully understand and exploit the potential of biological control agents. Furthermore, it's crucial to acknowledge the environmental impact of their long-term use.

Abstract: Bacterial biological control agents (BCAs) have been increasingly used against plant diseases. The traditional approach to manufacturing such commercial products was based on the selection of bacterial species able to produce secondary metabolites that inhibit mainly fungal growth in optimal media. Such species are required to be massively produced and sustain long-term selfstorage. The endpoint of this pipeline is large-scale field tests in which BCAs are handled as any other pesticide. Despite recent knowledge of the importance of BCA-host-microbiome interactions to trigger plant defenses and allow colonization, holistic approaches to maximize their potential are still in their infancy. There is a gap in scientific knowledge between experiments in controlled conditions for optimal BCA and pathogen growth and the nutrient-limited field conditions in which they face niche microbiota competition. Moreover, BCAs are considered to be safe by competent authorities and the public, with no side effects to the environment; the OneHealth impact of their application is understudied. This review summarizes the state of the art in BCA research and how current knowledge and new biotechnological tools have impacted BCA development and application. Future challenges, such as their combinational use and ability to ameliorate plant stress are also discussed. Addressing such challenges would establish their long-term use as centerfold agricultural pesticides and plant growth promoters.

Keywords: biological control agents; BCAs; bacterial biological control; environmental impact 


\section{Introduction}

Plant diseases caused by bacterial and fungal pathogens create major limitations on crop production with severe annual losses worldwide [1,2]. The consistent and efficient control of plant diseases may be extremely hard, facing pressure by consumer preferences for susceptible cultivars and changing environmental conditions [2]. New disease threats are emerging all over the world. Young grapevine decline caused by a complex of fungal poses a serious threat to the grapevine nursery and viticulture industry [3]. Diseases caused by bacterial pathogens, such as Xyllela fastidiosa and Pseudomonas syringae pv. actinidiae, which originated a few years ago in Italy and New Zealand, respectively $[4,5]$, have already become epidemics. Citrus greening accounts for the loss of over $50 \%$ of Florida's citrus plants and constitutes a global threat [6]. To respond to the growing list of pathogens, a pallet of local and systemic organic fungicides has been developed. In contrast, the already limited list of bactericides, mostly based on copper, is shortened due to concerns of residues in food and water and its environmental impact [7-9]. Biological control, the use of microbial antagonists termed as biological control agents (BCAs) to suppress diseases [10] gained ground in lieu of chemicals as a safe alternative for disease management [11]. Microbial BCAs are microorganisms such as bacteria, fungi, or viruses that attack specific plant pests. They affect pathogens with multiple modes of action which can be direct and/or indirect. The direct action is considered to result from competition for nutrients and environmental niches, antibiosis through secretion of harmful metabolites, and inhibition of pathogen colonization of the host plant. The indirect action includes induction of plant defenses and plant growth promotion [12].

This review aims to introduce BCAs to readers that are unfamiliar with crop protection and focus on the use of BCAs as bactericides. We focus on B. amyloliquefaciens, which dominates the market as a bio-bactericide. The scientific premise on its mode of action is analyzed and correlated to current approaches for the development of commercial formulations. Limitations of traditional methodologies are highlighted and the need for a holistic approach is suggested. Future challenges for researchers in agroindustry are analyzed, such as the need for improvement of active ingredients, the extension of their use, and environmental impacts. The scope of this article is to introduce BCAs to readers and highlight state-of-the-art research that has changed perspectives and their use. We used keyword research in popular databases such as Google Scholar, Scopus, and PubMed. The keywords used were BCAs, bacterial biocontrol agents, and environmental impact. Only articles published in English and from reputed journals from individual fields were considered. A sum of 196 publications was selected to follow the progress in the field across the globe over the past two decades.

\section{An Overview of Bacterial Pesticides}

\subsection{The Global Market}

Nowadays, it is crucial more than ever to protect our soils by reducing pesticides and agrochemicals by $30-50 \%$ in the next decade thus enhancing the health of every living organism including human life [13]. For this purpose, the use of biopesticides aims to replace pre- or post-harvest applications of conventional pesticides to eliminate their residues $[14,15]$. The global crop protection market offers several fungicidal products but a limited number of bactericidal compounds. The use of bacterium-based agents can provide a great source of microbicides.

Globally, the USA and Europe comprise the most extensive regional markets for biocontrol products [16]. In 2018, the global biofungicide market was estimated to be USD 1208.2 million and it is expected to reach USD 2877.2 million by 2024, as many big agrochemicals companies broaden their research and development (R\&D) section towards biocontrol [17]. Most of the bacterial strains commercialized as biopesticides, fungicides, and bactericides belong to Agrobacterium, Bacillus, and Pseudomonas genera (Table 1). Unlike bioinsecticides, which have been commercialized since 1938 [18], the first biocontrol agent, Agrobacterium radiobacter strain K84, was registered in 1979 against crown 
gall [15]. Currently, half of the commercial products are based on Bacillus species (Table 1), because of their multiple ways of action and their spore stability [19] which guarantee long shelf life. Pseudomonads face registration obstacles due to formulation issues and the risk to act as opportunistic human pathogens. Nevertheless, Blightban A506 (Pseudomonas fluorescens A506) has been registered for use against Erwinia amylovora, the causing agent of fire blight disease [20].

In Europe, the revised version of Regulation (EC) No. 1107/2009 directs commercialization [21]. A two-tier registration system is imposed to evaluate BCAs according to requirements for the active substance (e.g., identification, mode of action, toxicity testing) and formulation. Additionally, BCAs should be listed as an active substance based on peer review by all EU member states, the European Food Safety Authority (EFSA), and the European Commission [21]. Products that await authorization from every EU member country should be accompanied by efficacy and safety certifying data over a 24-month period. The legislative authorities of each EU member state accredit institutions to oversee field trials in accordance with Good Experimental Practice [21]. Predictably, the expensive EU registration procedures discourage small and medium-sized companies. For example, Pseudomonas chlororaphis (Cedomon) was registered 10 years after its file submission for suppression of soil-borne pathogens of barley and wheat [22]. Additionally, this is the reason why many plant growth-promoting bacteria which may have biocontrol effects are registered in the EU as biofertilizers than biopesticides [23].

On the contrary, the registration procedure in the USA is simplified because the Environmental Protection Agency (EPA), which supervises this procedure, handles biocontrol products as safer than chemical compounds [24]. This assumption helps to complete registration in a minimum of 12-24 months (compared with 84 months in Europe). Moreover, certain health and environmental safety assessments performed in the USA are considered insufficient by EU legislators and that explains why most US products are unavailable in the EU market [25].

The vast majority of bacterial BCAs are registered against fungal diseases, and some extended their label as bactericides based on additional evidence. For example, Bacillus amyloliquefaciens MBI 600 was primarily registered as a pesticide active ingredient against Aspergillus spp., Fusarium spp., and Rhizoctonia spp. in 1994 [26]. However, the latest revised label of Serifel, which contains the same BCA, refers to additional antibacterial action towards Erwinia spp., Pseudomonas spp., and Xanthomonas spp. [27]. In support, a study of 215 patents showed that the majority of potential microbial pesticide organisms had a fungicidal mode of action, and only seven indicated bactericidal activity [28]. 


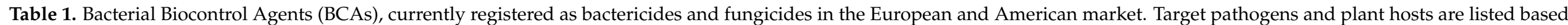
on label claims. Different colors in the target crop column indicate authorized use as bactericides (Bact), fungicides (F), or both (Both).

\begin{tabular}{|c|c|c|c|c|c|c|c|c|c|c|}
\hline \multirow{2}{*}{$\begin{array}{c}\text { Bacterial } \\
\text { BCAs }\end{array}$} & \multirow{2}{*}{$\begin{array}{l}\text { Brand } \\
\text { Name }\end{array}$} & \multirow{2}{*}{ Manufacturer } & \multirow{2}{*}{ Formulation } & \multirow{2}{*}{ Application } & \multicolumn{2}{|c|}{ Registration } & \multirow{2}{*}{ Target Fungal Diseases } & \multirow{2}{*}{$\begin{array}{l}\text { Target Bacterial } \\
\text { Diseases }\end{array}$} & \multirow{2}{*}{ Crops } & \multirow{2}{*}{ Authorizations } \\
\hline & & & & & Use & Region & & & & \\
\hline \multirow[b]{2}{*}{$\begin{array}{l}\text { Agrobacterium } \\
\text { radiobacter K84 }\end{array}$} & Galltrol-A & \multirow[b]{2}{*}{ AgBioChem } & Cell culture & $\begin{array}{l}\text { Cuts, roots, } \\
\text { seeds and stems } \\
\text { application }\end{array}$ & \multirow[b]{2}{*}{ Bactericide } & \multirow[b]{2}{*}{ US } & & $\begin{array}{l}\text { Crown gall } \\
\text { (Agrobacterium } \\
\text { tumefaciens) }\end{array}$ & $\begin{array}{c}\text { Bact: Non-food } \\
\text { bearing stone fruit and } \\
\text { nut trees }\end{array}$ & US:40230-1 \\
\hline & Gallex & & $\begin{array}{l}\text { Flowable } \\
\text { emulsion }\end{array}$ & $\begin{array}{l}\text { Gals and cuts } \\
\text { application }\end{array}$ & & & & $\begin{array}{l}\text { Crown gall } \\
\text { (Agrobacterium } \\
\text { tumefaciens), olive knot } \\
\text { (Pseudomonas } \\
\text { savastanoi) }\end{array}$ & $\begin{array}{l}\text { Bact: Oleander, olive, } \\
\text { ornamentals, stone } \\
\text { and nut fruit trees }\end{array}$ & US:40230-2 \\
\hline $\begin{array}{l}\text { Agrobacterium } \\
\text { radiobacter } \\
\text { (syn. strain } \\
\text { K1062 }\end{array}$ & Nogall & Basf & $\begin{array}{l}\text { Cells in peat } \\
\text { carrier (wettable } \\
\text { powder) }\end{array}$ & $\begin{array}{l}\text { Cuts, roots, } \\
\text { seeds and stems } \\
\text { application }\end{array}$ & Bactericide & US & & $\begin{array}{l}\text { Crown gall } \\
\text { (Agrobacterium } \\
\text { Tumefaciens) }\end{array}$ & $\begin{array}{l}\text { Bact: Non-food } \\
\text { bearing stone fruit and } \\
\text { nut trees, ornamentals }\end{array}$ & US:62388-1 \\
\hline \multirow[t]{2}{*}{$\begin{array}{l}\text { Bacillus amy- } \\
\text { loliquefaciens } \\
\quad \text { D747 }\end{array}$} & $\begin{array}{l}\text { Double } \\
\text { Nickel } 55\end{array}$ & \multirow[t]{2}{*}{$\begin{array}{l}\text { Certis USA } \\
\text { L.L.C }\end{array}$} & \multirow[t]{2}{*}{$\begin{array}{l}\text { Bacterial } \\
\text { endospores } \\
\text { (wettable } \\
\text { powder) }\end{array}$} & $\begin{array}{l}\text { Chemigation, } \\
\text { cut/root, foliar } \\
\text { and ground } \\
\text { application }\end{array}$ & \multirow[t]{2}{*}{$\begin{array}{l}\text { Bactericide, } \\
\text { fungicide }\end{array}$} & $\mathrm{EU}$ & $\begin{array}{l}\text { Blasts, blights, blotches, } \\
\text { damping-off diseases, } \\
\text { downy mildews, drops, } \\
\text { eutypa, flyspecks, leaf } \\
\text { curls, melanoses, molds, } \\
\text { mummy berry, phomopsis, } \\
\text { powdery mildews, rots, } \\
\text { rusts, scabs, scurfs, shanks, } \\
\text { shot hole, sigatoka, smuts, } \\
\text { spots, vine decline }\end{array}$ & $\begin{array}{l}\text { Blights, cankers, } \\
\text { specks and spots } \\
\text { (Erwinia spp. } \\
\text { Pseudomonas spp., } \\
\text { Xanthomonas spp.) }\end{array}$ & $\begin{array}{l}\text { Both: Citrus, pome } \\
\text { and stone fruit trees, } \\
\text { coffee, herbs and } \\
\text { spices, nut trees, } \\
\text { tropical fruits, } \\
\text { vegetables } \\
\text { F:Berries, cereal grains, } \\
\text { grapes, oilseed crops, } \\
\text { pomegranates, sugar } \\
\text { beets and tobacco }\end{array}$ & US: 70051-108 \\
\hline & Amylo-X & & & $\begin{array}{c}\text { Foliar } \\
\text { application }\end{array}$ & & US & $\begin{array}{l}\text { Blights, downy mildews, } \\
\text { molds, powdery mildews, } \\
\text { rots, sclerotinia }\end{array}$ & $\begin{array}{l}\text { Fire blight (Erwinia } \\
\text { amylovora), kiwi } \\
\text { canker (Pseudomonas } \\
\text { syringae pv. actinidiae) }\end{array}$ & $\begin{array}{l}\text { Bact: Kiwifruit pome } \\
\text { F: Berries grapes, } \\
\text { mushrooms, and stone } \\
\text { fruit trees, vegetables }\end{array}$ & $\begin{array}{c}\text { EU: Reg. No } \\
\text { 1316/2014 } \\
\text { (Dossier } \\
\text { complete } \\
\text { (2011/253/EU) }\end{array}$ \\
\hline \multirow{2}{*}{$\begin{array}{l}\text { Bacillus amy- } \\
\text { loliquefaciens } \\
\text { strain FZB24 }\end{array}$} & Taergo 2 & \multirow[t]{2}{*}{ Novozymes } & \multirow{2}{*}{$\begin{array}{l}\text { Bacterial } \\
\text { endospores } \\
\text { (wettable } \\
\text { powder) }\end{array}$} & $\begin{array}{l}\text { Cut/root, foliar } \\
\text { and ground } \\
\text { application, } \\
\text { ground } \\
\text { incorporation }\end{array}$ & \multirow{2}{*}{$\begin{array}{l}\text { Bactericide, } \\
\text { fungicide }\end{array}$} & US & $\begin{array}{l}\text { Damping off diseases, } \\
\text { blights, downy mildews, } \\
\text { molds, powdery mildews, } \\
\text { sclerotinia, spots }\end{array}$ & $\begin{array}{c}\text { Specks (Pseudomonas } \\
\text { spp.), spots } \\
\text { (Xanthomonas spp.) }\end{array}$ & $\begin{array}{l}\text { Both: Vegetables } \\
\text { F: Ornamentals }\end{array}$ & US:70127-12 \\
\hline & Taergo & & & $\begin{array}{c}\text { Foliar } \\
\text { application }\end{array}$ & & $\mathrm{EU}$ & $\begin{array}{c}\text { Blights, damping off } \\
\text { diseases, downy mildews, } \\
\text { molds, powdery mildews, } \\
\text { rots, spots }\end{array}$ & $\begin{array}{l}\text { Specks (Pseudomonas } \\
\text { spp.) }\end{array}$ & $\begin{array}{l}\text { Both: vegetables } \\
\text { F: Berries, grapes, }\end{array}$ & $\begin{array}{c}\text { EU: Reg. (EU) } \\
\text { 2017/806 }\end{array}$ \\
\hline
\end{tabular}


Table 1. Cont.

\begin{tabular}{|c|c|c|c|c|c|c|c|c|c|c|}
\hline \multirow{2}{*}{$\begin{array}{l}\text { Bacterial } \\
\text { BCAs }\end{array}$} & \multirow{2}{*}{$\begin{array}{l}\text { Brand } \\
\text { Name }\end{array}$} & \multirow{2}{*}{ Manufacturer } & \multirow{2}{*}{ Formulation } & \multirow{2}{*}{ Application } & \multicolumn{2}{|c|}{ Registration } & \multirow{2}{*}{ Target Fungal Diseases } & \multirow{2}{*}{$\begin{array}{l}\text { Target Bacterial } \\
\text { Diseases }\end{array}$} & \multirow{2}{*}{ Crops } & \multirow{2}{*}{ Authorizations } \\
\hline & & & & & Use & Region & & & & \\
\hline \multirow{5}{*}{$\begin{array}{l}\text { Bacillus amy- } \\
\text { loliquefaciens } \\
\text { (subtilis) MBI } \\
\quad 600\end{array}$} & \multirow[t]{2}{*}{ Serifel } & \multirow{5}{*}{ Basf } & \multirow[t]{2}{*}{$\begin{array}{c}\text { Bacterial } \\
\text { endospores } \\
\text { (wettable power }\end{array}$} & $\begin{array}{l}\text { Foliar and } \\
\text { ground } \\
\text { application }\end{array}$ & $\begin{array}{l}\text { Bactericide, } \\
\text { fungicide }\end{array}$ & US & $\begin{array}{c}\text { Anthracnose, blights, } \\
\text { blotches, damping off } \\
\text { diseases, diebacks, dots, } \\
\text { downy mildews, drops, } \\
\text { esca, eutypa, flyspeck, } \\
\text { molds, mummy berry, } \\
\text { phomopsis, powdery } \\
\text { mildews, rots, rusts, scabs, } \\
\text { shanks, scorches, scurfs, } \\
\text { shot hole, spots }\end{array}$ & $\begin{array}{l}\text { Aerial stem rot } \\
\text { (Erwinia carotovora) } \\
\text { cankers, specks and } \\
\text { spots (Pseudomonas } \\
\text { spp., Xanthomonas } \\
\text { spp.), fire blight } \\
\text { (Erwinia amylovora), } \\
\text { walnut blight } \\
\text { (Xanthomonas } \\
\text { campestris }\end{array}$ & $\begin{array}{l}\text { Both: Cereal grains, } \\
\text { grapes, herbs and } \\
\text { spices, oilseed crops, } \\
\text { soybean, tobacco, } \\
\text { sugar beets } \\
\text { berries citrus, pome } \\
\text { and stone fruit trees, } \\
\text { tree nuts, vegetables }\end{array}$ & US:71840-18 \\
\hline & & & & $\begin{array}{c}\text { Foliar } \\
\text { application }\end{array}$ & Fungicide & $\mathrm{EU}$ & Molds, sclerotinia & & $\begin{array}{l}\text { F: Berries, herbs and } \\
\text { spices, grapes }\end{array}$ & $\begin{array}{l}\text { EU: Reg. (EU) } \\
\text { 2016/1429Reg. } \\
\text { (EU) 540/2011 }\end{array}$ \\
\hline & $\begin{array}{l}\text { Histick N/T } \\
\text { (Beans, } \\
\text { peanut, } \\
\text { soybean) }\end{array}$ & & $\begin{array}{c}\text { Bacterial } \\
\text { endospores } \\
\text { (wettable power }\end{array}$ & Seed application & Fungicide & US & Damping off diseases & & $\begin{array}{l}\text { F: Beans, peanut, } \\
\text { soybean }\end{array}$ & US: 71840-2 \\
\hline & Integral & & $\begin{array}{c}\text { Aqueous } \\
\text { suspension }\end{array}$ & $\begin{array}{l}\text { Ground } \\
\text { application }\end{array}$ & Fungicide & US & Damping off diseases & & F: Peanut, soybean & US: 71840-5 \\
\hline & Subtilex & & $\begin{array}{l}\text { Bacterial } \\
\text { endospores } \\
\text { (wettable } \\
\text { powder) }\end{array}$ & $\begin{array}{l}\text { Foliar and } \\
\text { ground } \\
\text { application }\end{array}$ & Fungicide & US & $\begin{array}{l}\text { Damping off diseases, } \\
\text { downy mildews, molds, } \\
\text { powdery mildews }\end{array}$ & & $\begin{array}{l}\text { F: Bedding plants, } \\
\text { ornamentals, tropical } \\
\text { plants, vegetables }\end{array}$ & US: 71840-8 \\
\hline & Cease & Bioworks & $\begin{array}{l}\text { Aqueous } \\
\text { suspension }\end{array}$ & $\begin{array}{l}\text { Aerial and } \\
\text { ground } \\
\text { application, } \\
\text { chemigation }\end{array}$ & $\begin{array}{l}\text { Bactericide, } \\
\text { fungicide }\end{array}$ & US & $\begin{array}{l}\text { Anthracose, blights, } \\
\text { downy mildews, molds, } \\
\text { powedery mildews, rots, } \\
\text { rusts and sclerotinia }\end{array}$ & $\begin{array}{l}\text { Blight (Pseudomonas } \\
\text { syringae), fruit blotch } \\
\text { (Acidovorax avenae), } \\
\text { rots, specks and spots } \\
\text { (Erwinia spp, } \\
\text { Pseudomonas spp., } \\
\text { Xanthomonas spp.) }\end{array}$ & $\begin{array}{l}\text { Both: Berries, herbs } \\
\text { and vegetables }\end{array}$ & $\begin{array}{l}\text { US:264-1155- } \\
\quad 68539\end{array}$ \\
\hline & Rhapsody & & $\begin{array}{l}\text { Concentrated } \\
\text { cell suspension }\end{array}$ & $\begin{array}{l}\text { Chemigation, } \\
\text { foliar and } \\
\text { ground } \\
\text { application }\end{array}$ & $\begin{array}{l}\text { Bactericide, } \\
\text { fungicide }\end{array}$ & US & $\begin{array}{l}\text { Anthracnose, brown patch, } \\
\text { damping off diseases, gray } \\
\text { mold, spots, powdery } \\
\text { mildews, red thread, rust, } \\
\text { septoria }\end{array}$ & $\begin{array}{l}\text { Soft rot (Erwinia spp.), } \\
\text { spots (Erwinia spp., } \\
\text { Pseudomonas spp., } \\
\text { Xanthomonas spp.) }\end{array}$ & $\begin{array}{l}\text { Both: Landscape } \\
\text { plants F: Berries, citrus, } \\
\text { pome and stone fruit } \\
\text { trees, golf courses } \\
\text { lawns, turfs }\end{array}$ & US:264-1155 \\
\hline
\end{tabular}


Table 1. Cont.

\begin{tabular}{|c|c|c|c|c|c|c|c|c|c|c|}
\hline \multirow{2}{*}{$\begin{array}{c}\text { Bacterial } \\
\text { BCAs }\end{array}$} & \multirow{2}{*}{$\begin{array}{l}\text { Brand } \\
\text { Name }\end{array}$} & \multirow{2}{*}{ Manufacturer } & \multirow{2}{*}{ Formulation } & \multirow{2}{*}{ Application } & \multicolumn{2}{|c|}{ Registration } & \multirow{2}{*}{ Target Fungal Diseases } & \multirow{2}{*}{$\begin{array}{l}\text { Target Bacterial } \\
\text { Diseases }\end{array}$} & \multirow{2}{*}{ Crops } & \multirow{2}{*}{ Authorizations } \\
\hline & & & & & Use & Region & & & & \\
\hline \multirow{3}{*}{$\begin{array}{c}\text { Bacillus amy- } \\
\text { loliquefaciens } \\
\text { (subtilis) strain } \\
\text { QST } 713\end{array}$} & \multirow{2}{*}{$\begin{array}{l}\text { Serenade } \\
\text { Aso }\end{array}$} & \multirow{3}{*}{$\begin{array}{l}\text { Bayer Crop } \\
\text { science }\end{array}$} & \multirow{2}{*}{$\begin{array}{l}\text { Concentrated } \\
\text { cell suspension }\end{array}$} & $\begin{array}{l}\text { Foliar and } \\
\text { ground } \\
\text { application }\end{array}$ & \multirow{2}{*}{$\begin{array}{l}\text { Bactericide, } \\
\text { fungicide }\end{array}$} & US & $\begin{array}{c}\text { Anthracnose, bakanae, } \\
\text { blights, molds, damping } \\
\text { off diseases, melanose, } \\
\text { mummy berry, phomopsis, } \\
\text { pink root, post bloom fruit } \\
\text { drop, powdery mildews, } \\
\text { ramularia, rots, rusts, } \\
\text { scabs, sclerotinia, shot hole, } \\
\text { sigatoka, smut, spots, web } \\
\text { blotch }\end{array}$ & $\begin{array}{c}\text { Fruit blotch } \\
\text { (Actinovorax avenae), } \\
\text { blights, cankers, rots, } \\
\text { specks and spots } \\
\text { (Erwinia spp., } \\
\text { Pseudomonas spp., } \\
\text { Xanthomonas spp.), } \\
\text { gumming disease } \\
\text { (Xanthomonas spp.), } \\
\text { olive knot } \\
\text { (Pseudomonas } \\
\text { savastanoi), pustule } \\
\text { (Xanthomonas spp.) }\end{array}$ & $\begin{array}{l}\text { Both: Tropical fruits, } \\
\text { vegetables soybeans, } \\
\text { sugarcanes, tree nuts, } \\
\text { oilseed crops, olive, } \\
\text { kiwifruit, F: Cereal } \\
\text { grains, coffee, cotton, } \\
\text { herbs and spices, grass } \\
\text { seeds, grapes, } \\
\text { nongrass animal feeds, } \\
\text { peanut, pomegranate, } \\
\text { tobacco }\end{array}$ & US:264-1152 \\
\hline & & & & $\begin{array}{l}\text { Chemigation, } \\
\text { foliar and } \\
\text { ground } \\
\text { application }\end{array}$ & & $\mathrm{EU}$ & $\begin{array}{l}\text { Anthracnose, blights, } \\
\text { blotches, clubroot, molds, } \\
\text { damping off diseases, } \\
\text { downy mildews, } \\
\text { phomopsis, powdery } \\
\text { mildews, rots, rusts, scabs, } \\
\text { sclerotinia, sigatoga, spots }\end{array}$ & $\begin{array}{l}\text { Blights, cankers, rots, } \\
\text { specks and spots } \\
\text { (Erwinia spp., } \\
\text { Pseudomonas spp., } \\
\text { Xanthomonas spp.) }\end{array}$ & $\begin{array}{c}\text { Both: Citrus, pome } \\
\text { and stone fruit trees, } \\
\text { vegetables tropical } \\
\text { fruits, pomegranate, } \\
\text { Berries, } \\
\text { F: herbs and spices, } \\
\text { grapes, mushrooms, } \\
\text { oilseed crops, } \\
\text { ornamentals, tobacco, } \\
\text { sugar beets }\end{array}$ & $\begin{array}{c}\text { EU: Reg. (EU) } \\
\text { 2015/1396Reg. } \\
\text { (EU) } \\
\text { 2020/421Reg. } \\
\text { (EU) No } \\
540 / 2011 \\
\text { (07/6/EC, Reg } \\
\text { (EU) } \\
\text { 2019/168,Reg. } \\
\text { (EU) } \\
2018 / 524, \text { Reg. } \\
\text { (EU) No } \\
487 / 2014)\end{array}$ \\
\hline & $\begin{array}{l}\text { Serenade } \\
\text { Max }\end{array}$ & & $\begin{array}{l}\text { Bacterial } \\
\text { endospores } \\
\text { (wettable } \\
\text { powder) }\end{array}$ & $\begin{array}{l}\text { Aerial and foliar } \\
\text { application, } \\
\text { chemigation } \\
\text { ground } \\
\text { incorporation }\end{array}$ & $\begin{array}{l}\text { Bactericide, } \\
\text { fungicide }\end{array}$ & US & $\begin{array}{l}\text { Anthracnose, blights, } \\
\text { blotches, molds, damping } \\
\text { off diseases, downy } \\
\text { mildews, eutypa, flyspeck, } \\
\text { melanose, mummy berry, } \\
\text { phomopsis, post bloom } \\
\text { fruit drop, powdery } \\
\text { mildews, rots, rusts, scabs, } \\
\text { smuts, shot hole, spots }\end{array}$ & $\begin{array}{c}\text { Fruit blotch } \\
\text { (Actinovorax avenae), } \\
\text { blights, cankers, rots, } \\
\text { specks and spots } \\
\text { (Erwinia spp., } \\
\text { Pseudomonas spp., } \\
\text { Xanthomonas spp.), } \\
\text { gumming disease } \\
\text { (Xanthomonas spp.), } \\
\text { olive knot } \\
\text { (Pseudomonas } \\
\text { savastanoi), pustule } \\
\text { (Xanthomonas spp.) }\end{array}$ & $\begin{array}{l}\text { Both: Berries, cereal } \\
\text { grains, pome and } \\
\text { stone fruit trees, tree } \\
\text { nuts, tropical fruits, } \\
\text { vegetables F: citrus, } \\
\text { grass seeds, grapes, } \\
\text { nongrass animal feeds, } \\
\text { oilseed crops, peanut }\end{array}$ & US: 264-1151 \\
\hline
\end{tabular}


Table 1. Cont.

\begin{tabular}{|c|c|c|c|c|c|c|c|c|c|c|}
\hline \multirow{2}{*}{$\begin{array}{c}\text { Bacterial } \\
\text { BCAs }\end{array}$} & \multirow{2}{*}{$\begin{array}{l}\text { Brand } \\
\text { Name }\end{array}$} & \multirow{2}{*}{ Manufacturer } & \multirow{2}{*}{ Formulation } & \multirow{2}{*}{ Application } & \multicolumn{2}{|c|}{ Registration } & \multirow{2}{*}{ Target Fungal Diseases } & \multirow{2}{*}{$\begin{array}{l}\text { Target Bacterial } \\
\text { Diseases }\end{array}$} & \multirow{2}{*}{ Crops } & \multirow{2}{*}{ Authorization } \\
\hline & & & & & Use & Region & & & & \\
\hline & & & & $\begin{array}{c}\text { Foliar } \\
\text { application }\end{array}$ & & $\mathrm{EU}$ & $\begin{array}{l}\text { Blights, molds, rusts, scabs, } \\
\text { sclerotinia }\end{array}$ & $\begin{array}{l}\text { Blights, cankers, rots, } \\
\text { specks and spots } \\
\text { (Erwinia spp., } \\
\text { Pseudomonas spp., } \\
\text { Xanthomonas spp.), } \\
\text { crown gall } \\
\text { (Agrobacterium } \\
\text { tumefaciens }\end{array}$ & $\begin{array}{l}\text { Both: Berries, herbs } \\
\text { and spices, grapes, } \\
\text { pome and stone fruit } \\
\text { trees, tobacco, tropical } \\
\text { fruits, vegetables }\end{array}$ & $\begin{array}{c}\text { Reg. (EU) } \\
\text { 2015/1396Reg. } \\
\text { (EU) } \\
\text { 2020/421Reg. } \\
\text { (EU) No } \\
540 / 2011 \\
\text { (07/6/EC, Reg. } \\
\text { (EU) } \\
\text { 2019/168,Reg. } \\
\text { (EU) } \\
2018 / 524, \text { Reg. } \\
\text { (EU) No } \\
487 / 2014)\end{array}$ \\
\hline & $\begin{array}{l}\text { Serenade } \\
\text { Opti }\end{array}$ & & $\begin{array}{l}\text { Bacterial } \\
\text { endospores } \\
\text { (wettable } \\
\text { powder) }\end{array}$ & $\begin{array}{l}\text { Aerial and } \\
\text { ground } \\
\text { application, } \\
\text { chemigation }\end{array}$ & $\begin{array}{l}\text { Bactericide, } \\
\text { fungicide }\end{array}$ & US & $\begin{array}{c}\text { Anthracnose, blights, } \\
\text { blotches, molds, flyspeck, } \\
\text { mummy berry, phomopsis, } \\
\text { post bloom fruit drop, } \\
\text { powdery mildews, rots, } \\
\text { rusts, sclerotinia, shot hole, } \\
\text { spots }\end{array}$ & $\begin{array}{c}\text { Aerial Stem Rot } \\
\text { (Erwinia carotovora), } \\
\text { canker, (Pseudomonas } \\
\text { spp.), fire blight } \\
\text { (Erwinia amylovora), } \\
\text { shot hole (Xanthomonas } \\
\text { pruni), spots } \\
\text { (Pseudomonas spp., } \\
\text { Xanthomonas spp.), }\end{array}$ & $\begin{array}{c}\text { Botth: Berries, pome } \\
\text { and stone fruit trees, } \\
\text { tree nuts, vegetables } \\
\text { citrus, pomegranate, } \\
\text { stevia } \\
\text { F: Herbs and spices, } \\
\text { grapes, kiwifruit, } \\
\text { oilseed crops, peanut }\end{array}$ & US: $264-1160$ \\
\hline & $\begin{array}{l}\text { Serenade } \\
\text { Soil }\end{array}$ & & $\begin{array}{l}\text { Concentrated } \\
\text { cell suspension }\end{array}$ & $\begin{array}{l}\text { Ground } \\
\text { application }\end{array}$ & $\begin{array}{l}\text { Bactericide, } \\
\text { fungicide }\end{array}$ & US & $\begin{array}{l}\text { damping off diseases, pink } \\
\text { root, rots, sclerotinia }\end{array}$ & Rots (Erwinia spp.) & $\begin{array}{l}\text { Both: Vegetables F: } \\
\text { Berries, citrus fruit } \\
\text { trees, peanut }\end{array}$ & US: $264-1152$ \\
\hline & Jazz & & $\begin{array}{l}\text { Bacterial } \\
\text { endospores } \\
\text { (wettable } \\
\text { powder) }\end{array}$ & $\begin{array}{l}\text { Chemigation, } \\
\text { ground } \\
\text { incorporation }\end{array}$ & Fungicide & US & Molds & & F: Mushrooms & US: 264-1151 \\
\hline $\begin{array}{l}\text { Bacillus } \\
\text { mycoides } \\
\text { isolate J }\end{array}$ & Lifeguard & $\begin{array}{l}\text { Certis USA } \\
\text { L.L.C }\end{array}$ & $\begin{array}{l}\text { Bacterial } \\
\text { endospores } \\
\text { (wettable } \\
\text { powder) }\end{array}$ & $\begin{array}{l}\text { Aerial and } \\
\text { ground } \\
\text { application, } \\
\text { chemigation }\end{array}$ & $\begin{array}{l}\text { Bactericide, } \\
\text { fungicide }\end{array}$ & US & $\begin{array}{l}\text { Anthracnose, blights, } \\
\text { blotches, flyspeck, molds, } \\
\text { downy mildews, mummy } \\
\text { berry, powdery mildews, } \\
\text { rusts, scabs, spots }\end{array}$ & $\begin{array}{l}\text { Canker, spot and } \\
\text { speck (Pseudomonas } \\
\text { spp., Xanthomonas } \\
\text { spp.), fire blight } \\
\text { (Erwinia amylovora) }\end{array}$ & $\begin{array}{l}\text { Both: Citrus and pome } \\
\text { fruit trees, vegetables, } \\
\text { grapes, peanuts, } \\
\text { tobacco }\end{array}$ & US:70051-119 \\
\hline
\end{tabular}


Table 1. Cont.

\begin{tabular}{|c|c|c|c|c|c|c|c|c|c|c|}
\hline \multirow{2}{*}{$\begin{array}{l}\text { Bacterial } \\
\text { BCAs }\end{array}$} & \multirow{2}{*}{$\begin{array}{l}\text { Brand } \\
\text { Name }\end{array}$} & \multirow{2}{*}{ Manufacturer } & \multirow{2}{*}{ Formulation } & \multirow{2}{*}{ Application } & \multicolumn{2}{|c|}{ Registration } & \multirow{2}{*}{ Target Fungal Diseases } & \multirow{2}{*}{$\begin{array}{l}\text { Target Bacterial } \\
\text { Diseases }\end{array}$} & \multirow{2}{*}{ Crops } & \multirow{2}{*}{ Authorization } \\
\hline & & & & & Use & Region & & & & \\
\hline \multirow[b]{3}{*}{$\begin{array}{l}\text { Bacillus } \\
\text { pumilus QST } \\
2808\end{array}$} & Ballad Plus & \multirow[b]{3}{*}{$\begin{array}{l}\text { Bayer Crop } \\
\text { Science }\end{array}$} & $\begin{array}{l}\text { Aqueous } \\
\text { suspension of } \\
\text { bacterial } \\
\text { endospores, } \\
\text { solids and } \\
\text { solubles }\end{array}$ & $\begin{array}{l}\text { Aerial and } \\
\text { ground } \\
\text { application, } \\
\text { chemigation }\end{array}$ & $\begin{array}{l}\text { Bactericide, } \\
\text { fungicide }\end{array}$ & \multirow[b]{3}{*}{ US } & $\begin{array}{l}\text { Blights, molds, downy } \\
\text { mildews, powdery } \\
\text { mildews, rots, rusts, smuts, } \\
\text { spots, ramularia }\end{array}$ & $\begin{array}{l}\text { Blights and speck } \\
\text { (Pseudomonas spp., } \\
\text { Xanthomonas spp.), } \\
\text { pustule (Xanthomonas } \\
\text { spp.) }\end{array}$ & $\begin{array}{l}\text { Both: Cereal grains, } \\
\text { oilseed crops, } \\
\text { vegetables F: Grass } \\
\text { grown for seed } \\
\text { production, sugar } \\
\text { beets }\end{array}$ & US:264-1153 \\
\hline & Bay 2000 & & $\begin{array}{l}\text { Concentrated } \\
\text { cell suspension }\end{array}$ & Seed application & Fungicide & & Damping off diseases & & $\begin{array}{l}\text { F: Cereal grains, } \\
\text { vegetables }\end{array}$ & US:264-118 \\
\hline & Sonata & & $\begin{array}{l}\text { Water } \\
\text { suspension of } \\
\text { bacterial } \\
\text { endospores, } \\
\text { solids and } \\
\text { solubles }\end{array}$ & $\begin{array}{l}\text { Aerial and } \\
\text { ground } \\
\text { application, } \\
\text { chemigation }\end{array}$ & Fungicide & & $\begin{array}{l}\text { Blights, downy mildews, } \\
\text { powdery mildews, rusts, } \\
\text { scabs, spots }\end{array}$ & & $\begin{array}{l}\text { F: Berries, cereal } \\
\text { grains, citrus, pome } \\
\text { and stone fruit trees, } \\
\text { herbs and spices, } \\
\text { grapes, grass grown } \\
\text { for seed production } \\
\text { oilseed crops, roses, } \\
\text { sugar beets, sweet } \\
\text { corn, tree nuts, } \\
\text { vegetables }\end{array}$ & US:264-1153 \\
\hline $\begin{array}{l}\text { Pseudomonas } \\
\text { fluorescens } \\
\text { A506 }\end{array}$ & $\begin{array}{l}\text { BlightBan } \\
\text { A506 }\end{array}$ & $\begin{array}{c}\text { Nufarm } \\
\text { Americas Inc. }\end{array}$ & $\begin{array}{l}\text { Bacterial } \\
\text { endospores } \\
\text { (wettable } \\
\text { powder) }\end{array}$ & $\begin{array}{c}\text { Foliar } \\
\text { application }\end{array}$ & $\begin{array}{l}\text { Bactericide, } \\
\text { fungicide }\end{array}$ & US & Molds & $\begin{array}{l}\text { Fire blight (Erwinia } \\
\text { amylovora), sour rot } \\
\text { (Acetobacter spp.) }\end{array}$ & $\begin{array}{c}\text { Both: Berries, pome } \\
\text { and stone fruit trees, } \\
\text { vegetables }\end{array}$ & US:228-710 \\
\hline & $\begin{array}{l}\text { Actinovate } \\
\text { AG }\end{array}$ & & & $\begin{array}{l}\text { Chemigation, } \\
\text { cutting/root, } \\
\text { foliar, ground } \\
\text { and seed } \\
\text { application }\end{array}$ & $\begin{array}{l}\text { Bactericide, } \\
\text { fungicide }\end{array}$ & US & $\begin{array}{l}\text { Damping off diseases, } \\
\text { molds, rots }\end{array}$ & $\begin{array}{c}\text { Bacterial spot } \\
\text { (Xanthomonas } \\
\text { perforans), walnut } \\
\text { blight (Xanthomonas } \\
\text { arboricola pv. juglandis) }\end{array}$ & $\begin{array}{l}\text { Both: Stone fruit, } \\
\text { vegetables } \\
\text { F: Berries, cereal } \\
\text { grains, citrus, pome } \\
\text { fruit trees, herbs and } \\
\text { spices, grapes, } \\
\text { mushroom, oilseed } \\
\text { crops, soybean, tree } \\
\text { nuts, tropical fruits }\end{array}$ & US:73314-1 \\
\hline
\end{tabular}


Table 1. Cont.

\begin{tabular}{|c|c|c|c|c|c|c|c|c|c|c|}
\hline \multirow{2}{*}{$\begin{array}{l}\text { Bacterial } \\
\text { BCAs }\end{array}$} & \multirow{2}{*}{$\begin{array}{l}\text { Brand } \\
\text { Name }\end{array}$} & \multirow{2}{*}{ Manufacturer } & \multirow{2}{*}{ Formulation } & \multirow{2}{*}{ Application } & \multicolumn{2}{|c|}{ Registration } & \multirow{2}{*}{ Target Fungal Diseases } & \multirow{2}{*}{$\begin{array}{l}\text { Target Bacterial } \\
\text { Diseases }\end{array}$} & \multirow{2}{*}{ Crops } & \multirow{2}{*}{ Authorizations } \\
\hline & & & & & Use & Region & & & & \\
\hline \multirow{3}{*}{$\begin{array}{c}\text { Sreptomyces } \\
\text { lydicus WYE } \\
108\end{array}$} & $\begin{array}{l}\text { Actinovate } \\
\text { Lawn and } \\
\text { Garden }\end{array}$ & \multirow{3}{*}{ Novozymes } & \multirow{3}{*}{$\begin{array}{l}\text { Bacterial } \\
\text { endospores } \\
\text { (wettable } \\
\text { powder) }\end{array}$} & $\begin{array}{l}\text { Foliar, ground } \\
\text { application }\end{array}$ & $\begin{array}{l}\text { Bactericide, } \\
\text { fungicide }\end{array}$ & US & $\begin{array}{l}\text { Club root, damping off } \\
\text { diseases, downy mildews, } \\
\text { leaf curl, molds, patches, } \\
\text { powdery mildews, rots, } \\
\text { spots }\end{array}$ & $\begin{array}{c}\text { Bacterial spot } \\
\text { (Xanthomonas } \\
\text { perforans), bacterial } \\
\text { blast (Pseudomonas } \\
\text { syringae), citrus canker } \\
\text { (Xanthomonas axopodis } \\
\text { pv. citri) }\end{array}$ & $\begin{array}{l}\text { Both: Lawns, pome } \\
\text { and stone fruit trees, } \\
\text { ornamentals, } \\
\text { vegetables }\end{array}$ & US:73314-1 \\
\hline & $\begin{array}{l}\text { Actinovate } \\
\text { SP }\end{array}$ & & & $\begin{array}{c}\text { Cut/root, } \\
\text { ground and } \\
\text { seed application }\end{array}$ & Fungicide & US & $\begin{array}{c}\text { Anthracnose, blights, } \\
\text { damping off diseases, } \\
\text { downy mildews, molds, } \\
\text { patches, powdery mildews, } \\
\text { rusts, spots }\end{array}$ & & $\begin{array}{l}\text { F: Lawns, ornamentals, } \\
\text { vegetables }\end{array}$ & US:73314-1 \\
\hline & $\begin{array}{l}\text { Actinovate } \\
\text { STP }\end{array}$ & & & $\begin{array}{l}\text { Dry seed } \\
\text { application }\end{array}$ & & & $\begin{array}{l}\text { Collapses, damping off } \\
\text { diseases, rots, smuts }\end{array}$ & & $\begin{array}{c}\text { F: Cereal grains, } \\
\text { cotton, herbs and } \\
\text { spices, oilseed crops, } \\
\text { peanut, sugar beets, } \\
\text { vegetables }\end{array}$ & US:73314-4 \\
\hline
\end{tabular}




\subsection{The Discovery of Bacterial Biopesticides}

Over the past 120 years, research has repeatedly demonstrated that phylogenetically diverse microorganisms can act as natural antagonists of various plant pathogens [29]. The first commercial BCA against plant diseases, Bacillus subtilis, dates back to 1897 [30]. Notable examples of pioneer research include the first evidence of suppression of damping-off of pine seedlings [31] and potato scab disease [32] through the application of antagonistic fungi. Additionally, parasitism of the pathogen Rhizoctonia solani by Trichoderma (Gliocladium) virens, a well-known fungal BCA nowadays [33], and the use of Agrobacterium radiobacter and Pseudomonas fluorescens for prevention of crown gall on woody crops and fire blight in orchards, respectively [34,35].

In the late 1990s, competition assays led to the identification of several Pseudomonas and Bacillus species that were able to produce antibiotics and plant growth-promoting compounds, known as plant growth-promoting rhizobacteria (PGPRs) [36].

\subsection{The Traditional Approach to Develop Bacterial Pesticides}

The traditional approach to manufacturing a commercial BCA product is to isolate strains from disease-suppressive soils, test, produce industrially, preserve, store, and formulate them [37]. Efficacy evaluation of such microorganisms is mostly based on the secretion of a broad spectrum of secondary metabolites with antimicrobial activity [11]. In vitro testing of biocontrol activity is biased in favor of antibiosis biocontrol but excludes the contribution of other modes of action. In the two past decades, this approach has been evolved and additional criteria were proposed based on the multiple modes of action of biocontrol agents including competition for nutrients and space, successful colonization under different environmental conditions, and stimulation of plant-induced resistance (ISR) [38-40]. Adhesion to plant roots and formation of biofilm, both being prerequisites for colonization and establishing relationships with host plants, are also taken into account [37]. Biofilm is a self-produced extracellular matrix [41] that allows the exchange of nutrients, toxins, and protection from environmental stresses and antimicrobial compounds [42].

Most bacteria grow planktonically in vitro and solid minimal media are needed to visualize their innate ability to form biofilms. B. amyloliquefaciens strain MBI600, however, has an innate ability to spontaneously form biofilms; it can form biofilms in media that favor planktonic growth. We observed, through Leica SP8 time-lapse confocal microscope, that single MBI600 cells became sessile, duplicated, and organized in chains Figure 1 (1-3) (Video S1). Then, they adhered to each other and formed a colony with guard cells at its edges facilitating a coordinated expansion Figure $1(4-6)$. Three to four $h$ later, cells emerged on a second layer Figure 1 (7-9), growth was suspended on the base of the biofilm which gained height and formed a matrix Figure 1 (10-12) (Video S1). This contrasts with (other) Bacillus spp. growth in planktonic media where colonies primarily expand in width to cover the available nutrient medium. 


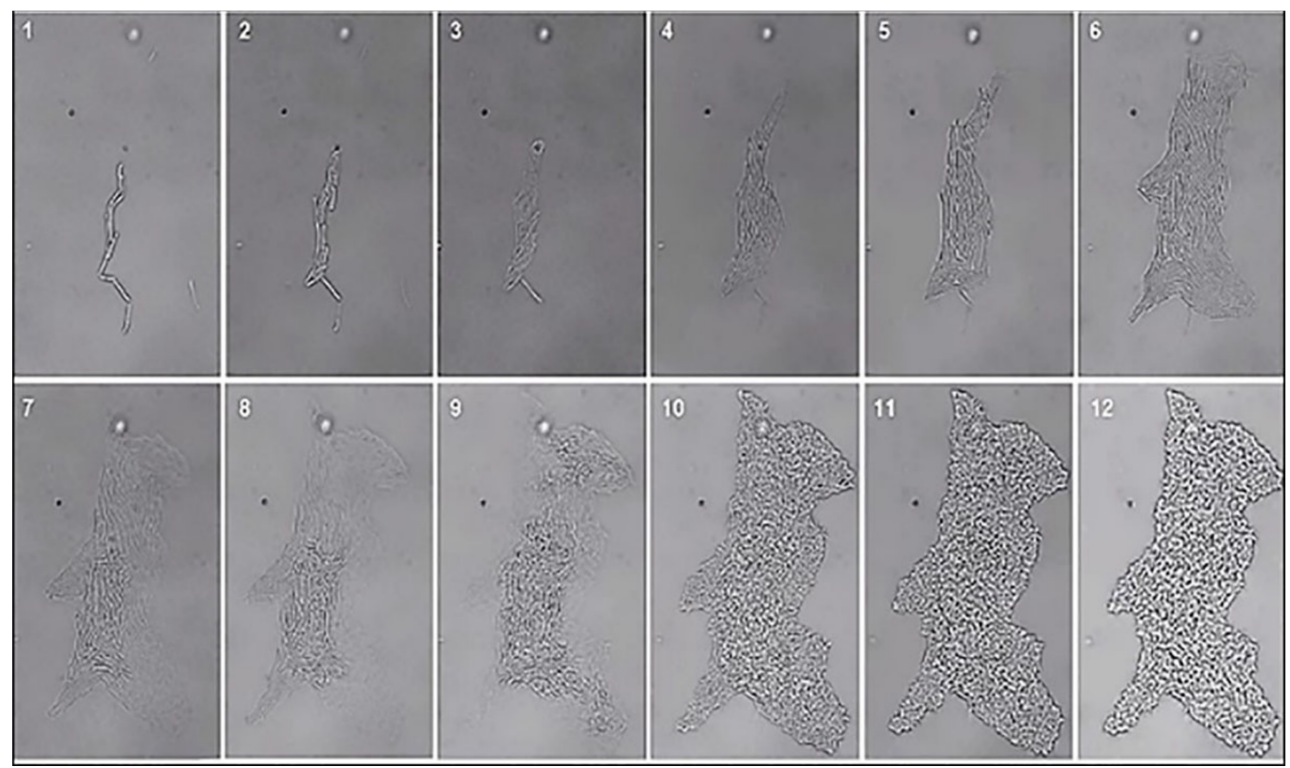

Figure 1. B. amyloliquefaciens strain MBI600 (the active ingredient of Serifel, BASF SE) spontaneously forms biofilms. Based on a previously described method [43], MBI600 single cells were observed in LB agar medium using a Leica SP8 time-lapse confocal microscope, over a $9 \mathrm{~h}$ period.

\section{Shifting Perspectives in BCA Mode of Action and Application}

The success of biological control involves a deep understanding of the modes of action of the antagonist, its interactions with the plant and the pathogen, and the mode and dose of application as well [44]. An important parameter affecting many aspects of the biocontrol effect is the formulation of BCAs [15]. The biocontrol performance relies also on the colonization of the plant surface by biocontrol agents on specific physiological stages of the plant in order to develop a sufficiently high level of resistance [45]. For example, experimental results suggest that optimum fire blight control can be achieved by applying Pseudomonas fluorescens A506 during the main bloom with repetitive applications at 7 to 10-day intervals to achieve colonization of delayed blossoms [46]. Moreover, it can be observed from Table 1 that every formulation is designed for a specific application according to registration files. As with any biological system, three factors that influence attainment are water, food, and the environment. Water activity affects crucially the survival of biocontrol agents in formulations. However, a dry product is more favorable than other formulations, due to less weight to ship and the significantly lower risk of contamination [47].

\section{1. "Let Them Eat Cake": Antibiotic Production Is Conditional}

Antibiotics are low-molecular-mass products of secondary metabolism, secreted by bacterial BCAs to compete with other bacteria for nutrients and space in an environmental niche (Figure 1). Such compounds exhibit antimicrobial activity by inhibiting pathogen growth at low concentrations. Two genera, Pseudomonas and Bacillus, have been well studied for the production of such antibiotics and their impact on disease management [48-50]. The most well-known antibiotic, pyrrolnitrin, is naturally produced by Pseudomonas spp.; after being processed, the fungicide fludioxonil can be derived [51]. Several other antibiotic compounds such as pyoluteorin, hydrogen cyanide, phloroglucinols, and cyclic lipopeptides have been characterized as being produced by Pseudomonads [52]. Pyoluteorin and 2,4 diacetylphloroglucinol (2,4 DAPG) are antibiotics produced by P. fluorescens strains that have a strong inhibitory effect against the phytopathogen Xanthomonas oryzae pv. oryzae [53]. On the other hand, Bacillus spp. seem to exhibit the strongest inhibitory effect against a broader range of phytopathogenic bacteria due to the plethora of the produced antimicrobial compounds [54]. This antimicrobial spectrum includes (i) ribosomal pep- 
tides, bacteriocins, which inhibit the growth of Gram-positive bacteria such as Bacillus spp., Clostridium spp. and Staphylococcus sp. $[55,56]$ or Gram-negative bacteria such as Agrobacterium tumefaciens [57], (ii) polyketides (PKS) with an antibacterial effect against Erwinia amylovora, Xanthomonas oryzae and Ralstonia solanacearum [58,59], (iii) non-ribosomal peptides and lipopeptides (NRPs and LPs) with strong antifungal activity apart from surfactins which have been shown to inhibit pathogenic bacteria such as $R$. solanacearum and Xanthomonas spp [60,61].

The production of antibiotics is regulated by various environmental factors such as carbon sources, temperature, $\mathrm{pH}$, and oxygen availability [62,63] (Figure 1). For example, high temperatures $\left(>37^{\circ} \mathrm{C}\right)$ favor the production of surfactins while low temperatures that of fengycins and iturins [64]. Additionally, the depletion of carbon, nitrogen, phosphate, iron, or other nutrient sources can trigger the secondary metabolism and thus the production of antibiotics. Indeed, Duffy and Défago [65] have shown that glucose was able to stimulate antibiotic production in almost all Pseudomonas strains, while phosphate repressed it. Similar findings of phosphate were observed for kanosamine production of Bacillus cereus [66].

In current biocontrol efficacy evaluation tests in vitro, pathogen susceptibility against secondary metabolites with antibiotic function is often assessed on nutrient media in which microbial antagonists coexist in dual cultures. Alternatively, targeted microorganisms are grown either in the presence of the culture supernatant of a particular BCA or the purified concentration of the metabolite. Although these approaches have many advantages, one main disadvantage is that the production of antimicrobial metabolites depends on the nutrient concentration of the chosen medium. According to Lugtenberg et al. [67], nutrient media that are being used in these bioassays are 100 times richer in nutrients than rhizosphere, thus quantities of secondary metabolites are higher at in vitro systems compared to natural habitats.

In parallel with advances regarding the abiotic conditions and nutrient effect on antibiotic production by $\mathrm{BCAs}$, research also has focused on respective effects by interspecific competition [68-70] (Figure 2). Because of the importance of biotic and abiotic factors that make antibiotic production conditional, new techniques are needed to optimize the evaluation of the actual amount of bacterial metabolites produced in situ compared to in vitro experiments [71,72].

\subsection{The Role of Siderophores in Biocontrol}

In support of the fact that major antimicrobial metabolites might not be produced when a BCA grows planktonically in axenic cultures, our group recently observed that the pallet of antimicrobial metabolites is extended under nutrient starvation [73]. In specific, they showed that production of the siderophore bacillibactin by B. amyloliquefaciens MBI 600, under iron limiting conditions, restrained in vitro and in planta growth of non-susceptible bacterial and fungal pathogens.

Siderophores are small non-ribosomal peptides secreted by bacteria, fungi, and plants. They function as high-affinity ferric chelators which solubilize iron before transport facilitate iron absorption and storage in iron-deprived niches [74,75]. Bacteria produce hydroxamate, catecholate, and in a few cases carboxylate types of siderophores, while fungi produce mainly hydroxamate and carboxylate types of siderophores [76].

Siderophores provide a selective advantage over microbial competitors [77] but also facilitate plant-microbe interactions [78] and are important for pathogen virulence [79]. In fact, microbes utilize siderophores produced by other microorganisms and are therefore referred to as xenosiderophores [80,81]. Even if the importance of siderophores for bacterial competition has been suggested decades ago [82], they have not been exploited in agriculture. Innovative medical uses of siderophores, such as the selective mediation of antibiotics to resistant clinical bacteria (Trojan horse strategy) [83] could be adopted in crop protection. 


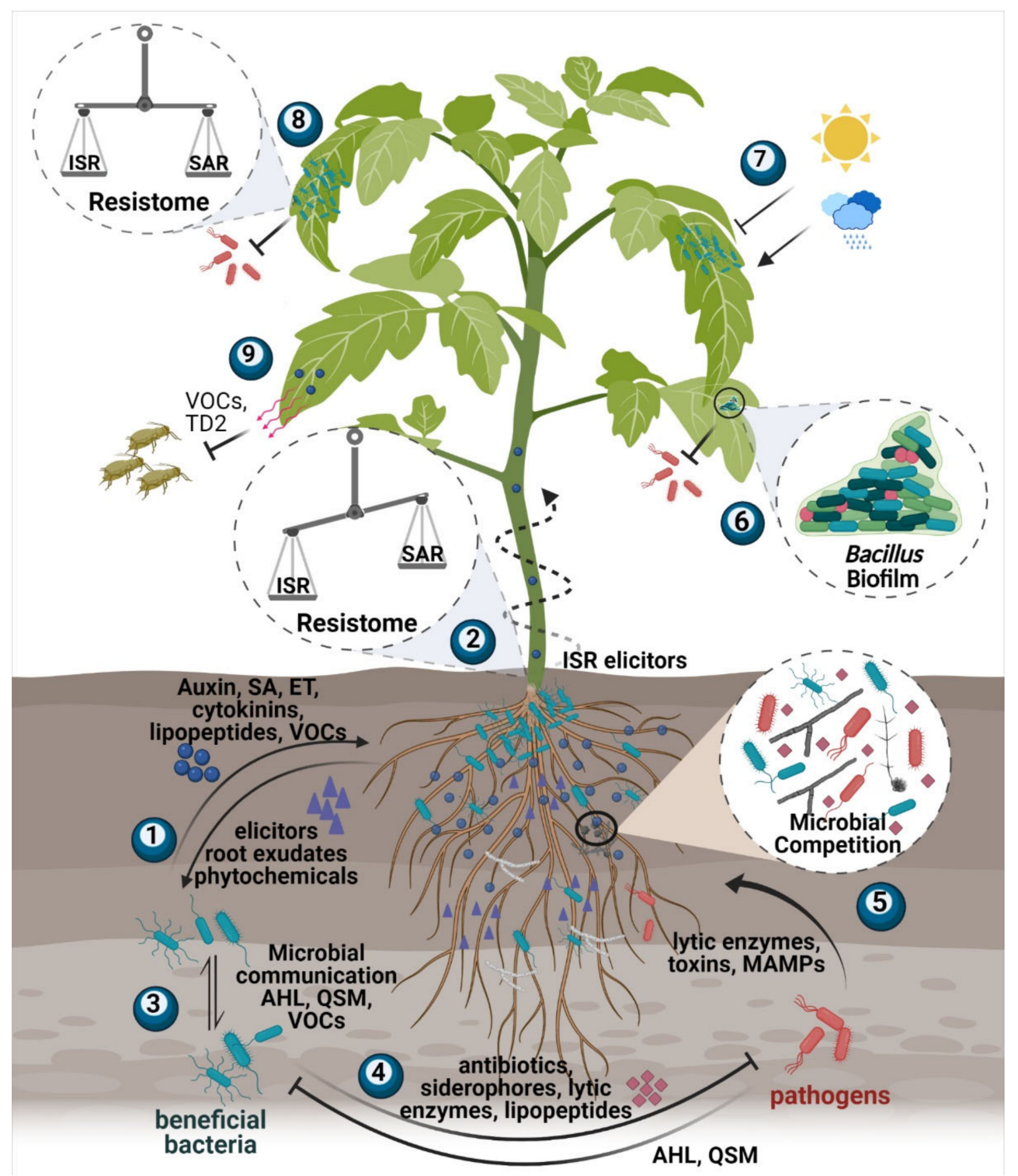

Figure 2. A schematic representation of the multifaceted interactions among BCAs, host plants, pathogens, and plant microbiota. Following rhizosphere application, BCAs and other beneficial bacteria perceive host signals and are recruited by the plant host (1). BCAs colonize roots and provide metabolites to plant roots that support growth and activate signaling pathways that trigger the Induced Systemic Resistance (ISR) and suppress Systemic Acquired Resistance (SAR) signaling (2). In parallel, BCAs interact with rhizosphere microbiota. This involves inter- or intra-specific communication by secretion of quorum sensing molecules (3) or antagonism with commensal bacteria and plant pathogens. Antagonism involves antibiosis by the production of bactericidal metabolites (4) and competition for nutrients and space (5). BCA colonization of the plant is largely dependent on its ability to form biofilm on roots but especially on leaves and crops in which the epidermis is a nutrient-limited hostile environment (6). Colonization of aerial parts largely depends on environmental conditions (7), humidity being the dominant factor. Following leaf colonization, microbial elicitors are perceived by plant receptors and trigger synergistically ISR and SAR (8) but also defense responses to insect pests by the production of volatile compounds of insecticidal enzymes (9). SA, Salicylic Acis; ET, Ethylene; VOCs, Volatile Organic Compounds; AHLs, N-Acyl homoserine lactone; QSM, Quorum Sensing Molecules; MAMPs; Microbe-Associated Molecular Patterns; ISR, Induced Systemic resistance; SAR, Systemic Acquired Resistance; TD2, Threonine dehydratase 2 biosynthetic protein. This illustration was created using the BioRender online software (https:/ / biorender.com/ accessed on 21 January 2020). 


\subsection{Reciprocal Perception Enables Host-Microbe Interactions}

Competitive host colonization is crucial for a BCA to protect against diseases and to interact with the plant as a PGPR. Their ability to occupy space on plant rhizosphere and phyllosphere depends on biotic and abiotic parameters such as the host species, soil type, nutrient competitors, niche microbiota, $\mathrm{pH}$, drought, salinity, etc. [84-87]. Plant roots exert considerable control over the composition of the rhizomicrobiome through the release of a wide range of chemoattractants and repellents including sugars, polysaccharides, amino acids, aromatic acids, aliphatic acids, fatty acids, sterols, phenolics, enzymes, proteins, plant growth regulators and secondary metabolites [88-90] (Figure 2). For example, precursors of plant phytohormones such as tryptophan (for indole-3-acetic acid) and aminocyclopropane1-carboxylic acid (ACC) (for ethylene) are concentrated in the root tip region [91,92] and attract PGPR that uses them for the biosynthesis of phytohormones reviewed in [85]. PGPR-derived auxins (e.g., IAA) trigger physiological responses that induce defense induction [93] and activate auxin-responsive genes that enhance plant growth and increase their biomass [94].

B. amyloliquefaciens strains have been shown to efficiently colonize the roots of Arabidopsis thaliana [95], Lactuca sativa [96], and other plants and overcome the antibacterial action of some plant root exudates [97] and perceive organic acids (malic and citric), polyamines (spermine) and other root exudates by methyl-accepting chemotaxis proteins in a kinase D mediated pathway to biosynthesize components and activate flagella and swarming movement while reducing biofilm formation [98]. Swarming is an adaptation of their locomotion machinery to achieve a specialized form of flagellum-driven motility in solid surfaces [99], mediated by the production of lipopeptide bio-surfactants that lower the surface thus facilitating movement [42] (Figure 3).

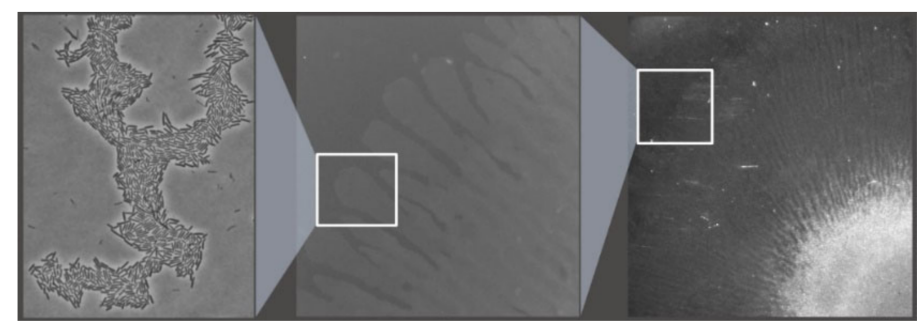

Figure 3. A multicellular B. amyloliquefaciens MBI600 community forms a biofilm in (M9) minimal media (A) but exhibits swarming motility when a synthetic analog of the root exudate malic acid (Merck) is added to the medium.

In contrast to the rhizosphere, the phyllosphere is an extreme and unstable habitat on which bacterial communities face acute fluctuations in temperature, humidity, and UV light irradiation and face limited access to nutrients [100,101] (Figure 2). Several studies are exhibiting that phyllosphere colonization by bacterial communities helps promote the wellness of the plant in many ways such as biocontrol, plant growth promotion, bioremediation of harmful chemicals, etc. [102]. In contrast to plant-pathogen leaf interactions [103], information on BCA-host leaf interactions and the reciprocal perception of signals is understudied.

\subsection{BCAs Trigger Multifaceted Defense Responses}

Successful BCA colonization results in plants exhibiting alterations of the biosynthetic and signaling pathways of phytohormones, activating components of the oxidative burst mechanism, and producing secondary metabolites that trigger defense responses in the presence of pathogens [104,105] or prime plants against potential pathogen attack [106]. Such responses are thought to be mediated by Jasmonic acid (JA) and Ethylene (ET) in an NPR1-dependent signaling pathway that triggers the induced systemic resistance (ISR) while suppressing salicylic acid (SA) levels and downstream signaling that induces the systemic acquired resistance (SAR) [107-109]. In support, Bacillus amyloliquefaciens FZB42 
was able to enhance the expression of defense marker genes such as $p r 1$ (SA marker gene) and pdf1.2 (JA/ET marker gene) in lettuce plants, while the co-existence of FZB42 and the lettuce pathogen Rhizoctonia solani activated only pdf1.2 expression levels compared to $p r 1$ which expression levels were lower than the control FZB42 [110].

Our group recently found that $B$. amyloliquefaciens MBI 600 interacts with its tomato host by triggering a signaling network that differentially induced defense signaling pathways depending on plant part and dose of application [111] (Figure 2). In specific, the suggested dosage of the commercial formulation of MBI 600 (Serifel) induced defense by mediating synergistic cross-talk between JA/ET and SA-signaling. Low dosage primed plant defense by activation of SA-responsive genes, which reduced up to $80 \%$ the incidence of Tomato spotted wilt virus and delayed Potato virus Y systemic accumulation [112].

Diverse genera of BCAs have been reported to trigger ISR through the production of volatile compounds (2,3-butanediol) and lipopeptides (surfactins and fengycins) [113] causing significant reductions in the severity of various bacterial diseases in a diversity of host plants [114]. For instance, B. amyloliquefaciens IN937a secreted volatiles which triggered ISR in Arabidopsis seedlings challenged with the pathogen Erwinia carotovora subsp. carotovora cause of the soft rot disease [113]. Similar findings were reported for Bacillus subtilis QST 713 which successfully reduced disease severity of bacterial speck (Pseudomonas syringae pv. tomato) on tomato plants by triggering defense-related genes [115]. Additionally, Raaijmakers et al. [116] reported that circular lipopeptides surfactin and fengycin were capable of eliciting ISR in tomato plants and beans. Recently, a synergistic action of multiple secreted elicitors was detected in B. amyloliquefaciens SQR9 that induced ISR against the bacterial pathogen Pseudomonas syringae pv. tomato DC3000 through different signaling pathway genes [117].

The significant progress in the understanding of BCA-mediated induction of defense responses has allowed this area of research to turn from basic to translational. Nowadays BCAs are thought to indirectly affect non-target pests, such as viruses and insects. Advances in the usage of BCAs against plant viruses have been recently reviewed [118]. Leaf colonization by BCAs has been reported to induce JA-mediated resistance to herbivorous insects [119]. The colonization of plant roots by the rhizobacterium Pseudomonas simiae WCS417r elicits higher expression of the JA/ET dependent ORA59-branch than the JAdependent MYC2 branch and triggers ISR against leaf-chewing insects [120]. In support, root colonization of cotton plants by Bacillus sp. induces JA levels rendering resistance against the herbivore Spodoptera exigua [121]. Additionally, colonization of tomato plants by mycorrhiza can prime systemic defense responses against insect attacks with increased expression of defense-associated genes allene oxide cyclase $(a \circ c)$, loxD and protease inhibitors (PI-I, PI-II) [122]. B. amyloliquefaciens MBI600 have been reported to trigger ISR against insects through the expression of the JA-dependent MYC2 branch [111].

\subsection{The Environmental Impact of Bio-Microbicides}

Despite the effective control of plant diseases, chemical microbicides form a hazard for the environment due to contamination of surface and groundwater [123,124], soil [125-127], vegetation, and non-target organisms $[128,129]$. Moreover, they pose a serious risk to human health [130-132]. BCAs were introduced as an alternative crop protection method with minimum risk to the environment and human health. However, is this the case?

The massive release of $\mathrm{BCAs}$ has been hypothesized to have an impact on the plant microbiome. Low-throughput methods at first (plating, DGGE, FISH, Sanger sequencing) and high-throughput methods recently (next-generation sequencing) have analyzed the rhizosphere, and secondarily the phyllosphere microbiota following BCA application $[133,134]$. Overall, it appears that bacterial BCAs have a minor and transient effect on the microbiome after soil application [135-140], independently of the soil type and properties [141-145]. Interestingly, a study by Erlacher et al. [40] suggested that the plant microbiota shifted due to pathogen attack by Rhizoctonia solani, but B. amyloliquefaciens FZB42 reduced that effect. 
Qin et al. [146] also reported that interactions between BCAs and the microbial community might be beneficial for the plants in terms of controlling the bacterial wildfire disease.

The large-scale application of BCAs is recent and sporadic. Long-term effects of continuous application of these dominant environmental species in commensal bacteria, insect, and animal microbiota have not been studied yet and animal models are currently used to be assessed for acute toxicity rather than indirect effects [147].

\subsection{The Multidisciplinary Approach to Study BCAs}

BCA strains have been selected to be used in commercial microbicide formulations based on in vitro sensitivity tests and field trials [148].

Even if competitive host colonization is necessary for success in field trials, it has been understudied, and assumed rather than proved. Rhizosphere studies focus on the functional characterization of genes involved in biofilm formation $[149,150]$ and monitor colonization based on microscopy, rather than actual counts of populations [151]. In support, B amyloliquefaciens MBI600 was found to successfully colonize primary roots of cucumber plants depending on the growth substrate of the roots [152]. Additionally, they have been based so far on artificial planting systems. Such systems utilize sterile substrates and hydroponics to eliminate rhizosphere microbiota and thus background bacteria in population counts. Unavoidably, they overlook niche competition that occurs in soil. Colonization of BCA in the phyllosphere is challenging due to the low availability of nutrients and organic matter on plant leaves. Although there is a scarcity of information about the colonization of BCAs in the phyllosphere [97], recent studies are indicating their abundance in the phyllosphere microbiota $[153,154]$. Wei et al. [145] have shown that $B$. subtilis was not only capable of maintaining on the leaves of strawberry for 8 days after application but also of increasing its abundance on new leaves. Colonization studies of BCA, other than Bacillus sp., have been sporadically reported on flower blossoms $[45,155]$.

The low cost and massive sequencing of bacterial species [156,157] might reverse the procedure to develop BCAs. Identification of dominant environmental species by microbiota profiling of the rhizosphere and phyllosphere of economically important plant species allows us to rapidly identify numerous BCA candidates that successfully colonize plants, and colonization tests can be targeted and specific to confirm such potential. Whole-genome [152] and RNA sequencing [158], pathway analysis [159], and metabolomic analysis $[160,161]$ is a fast way to identify the production of secondary metabolite microbicidal function under real environmental conditions [162] rather than optimal in vitro growth.

As aforementioned, BCA application is thought to affect herbivory by modification of plant signaling [163]. Plant and insect microbiome studies now supported an additional, indirect, effect to herbivory: BCA application might have a protective effect against the compositional shifts in leaf microbiota caused by herbivory, causing dysbiosis and increasing susceptibility to secondary bacterial infection [164]. BCAs are not, however, expected to directly affect herbivory. Insect bacteriocytes, haemolymph, gut, and salivary gland microbiota present low diversity, dominated by species (mostly Enterobacteriaceae) [165] different from those colonizing plants. It is therefore unlikely that shifts in plant microbiota by BCA application will lead to indirect effects to insects by the acquisition of microbial communities or genetic exchanges [166].

\section{Future Challenges}

The role of beneficial microorganisms is gaining importance in stress management and the development of climate change resilient agriculture. B. amyloliquefaciens has been found to increase abiotic stress tolerance [167] by accumulating compatible osmolytes such as proline, soluble sugars, etc. that help plants to maintain osmotic turgor [168] and thus alleviate salt tolerance [169]. For example, B. amyloliquefaciens SQR9 had enhanced salt stress tolerance of Arabidopsis thaliana and maize seedlings compared with the untreated samples through the increased total soluble sugar content leading to decreased cell death and enhanced peroxidase/catalase activity [170]. Additionally, the resistance of soybean 
under water-deficit conditions post application of thuricin 17 was observed due to the modifications of root structure, the increased root biomass and length, and the induced ABA and total nitrogen content [171]. All this is not of surprise, given the fact that Bacillus spp. dominate plant microbiomes under conditions of high temperature, salinity, and drought such as in Egypt [172].

Pseudomonas putida MTCC5279 also ameliorated drought stress in chickpea plants by modulating membrane integrity, osmolyte accumulation (proline, glycine betaine), and ROS scavenging ability. Similarly, PGPR might also help plants cope with flooding stress. Treatment of rice seedlings with the ACC deaminase-producing Pseudomonas fluorescens REN1 increased root elongation under constantly flooded conditions and salt stress effects were deteriorated [173]. Variovorax paradoxus 5C-2, an ACC deaminase-producing PGPR, enhanced salt tolerance, increased antioxidant enzyme activities, and upregulated ROS pathway genes of okra (Abelmoschus esculentus L.) plants under salinity stress [174]. A gibberellin-producing PGPR, Serratia nematodiphila increased pepper growth under lowtemperature stress conditions. The inoculated pepper plants showed higher levels of GA and ABA but lower for salicylate and jasmonate [175]. Inoculation with Burkholderia phytofirmans PsJN modulated carbohydrate metabolism to reduce chilling damage to grapevine [176].

Numerous studies have been reported that combinational use of BCAs has improved the consistency of biocontrol across sites with variable conditions. Successful biocontrol using mixtures of BCAs has been tested against late blight in potato [177] cucumber, chili, and poplar diseases [178-181]. BCA combinations do not always provide increased control, as an antagonism between the BCAs may occur. For example, mixtures of Pseudomonas fluorescens A506, Pantoea vagus C9-1, and Pantoea agglomerans Eh252 were less effective than individual strains against Erwinia amylovora infection of pear blossoms, because peptide antibiotics of Pantoea spp. were degraded by an extracellular protease of $P$. fluorescens A506 [35]. A meta-analysis of experimental studies evaluating the combinational use of BCAs revealed that 10 out of 465 treatments indicated synergistic interactions, 70 cases resulted in improved efficacy, and 64 cases with significant antagonism [182].

Combining bioremediation with plant growth promotion could be a beneficial approach. A mixture of B. amyloliquefaciens with the fungal strain Trichoderma virens improved yields of corn and tomato, among other crops [183], and is commercially available. Combinations of Trichoderma sp. with Bradyrhizobium sp., for improved growth of soybean, and arbuscular mycorrhizal fungi and Trichoderma harzianum for improved growth and soilborne pathogen control are also commercially available [184,185]. Early attempts to utilize bacterial consortia had inconsistent effects on crop yield [186]. Recently, however, many studies are indicating the contribution of BCAs consortia to plant growth promotion $[187,188]$.

A merging field of discovering new biocontrol agents is endophytes [189]. Endophytic bacteria confer plant growth promotion and suppression of biotic and abiotic stresses [190]. Important questions remain unanswered about the use of endophyte BCAs in crop production. Even if there is an urge to classify microbes as endophytic and develop them as BCAs, this qualification may be altered if they are found to cause disease in some plant species [191]. At present, there is a knowledge gap about genome differentiation between bacterial endophytes and plant pathogens [192]. Moreover, they may be passively absorbed by roots, since there is limited evidence of internally colonizing host species [37]. Additionally, endophytic inoculations are often unsuccessful in field experiments due to establishment problems [193]. Developing inocula containing highly effective microbes with a long shelf-life and high rhizosphere colonization rate poses a major challenge for commercialization.

Furthermore, technological developments in biotechnology open new possibilities in biocontrol such as genetic modification [194]. Despite all efforts, no genetically modified microorganisms (GMMs) with action are registered in the European Union (EU) yet, and only a few in the rest global market [195]. 


\section{Conclusions}

Despite the discovery of their pesticide function several decades ago, biological control agents practically were developed as biopesticides during the past decade. This was largely due to the poor understanding of their biology and interaction with hosts and the traditional approach to their development. The specialization of microbiologists in BCAs and biotechnology tools helped us understand their true potential. Scientists and the agroindustry shift, hesitantly, their focus from the production of secondary metabolites, which is conditional, to the exploitation of the triple BCA-host-microbe interaction in order to fully exploit BCAs for addressing crop production issues, including but not limited to disease protection.

Supplementary Materials: The following are available online at https:/ /www.mdpi.com/article/10 .3390/biology10111202/s1, Video S1: Biofilm formation by B. amyloliquefaciens MBI600.

Author Contributions: Conceptualization, N.S. and I.T.; writing—original draft preparation, A.D., I.T., A.V., D.P. and N.S; writing-review and editing, A.D., I.T, A.T., G.M., N.J.P. and N.S. All authors have read and agreed to the published version of the manuscript.

Funding: The APC was funded by BASF SE, grant number PAR00415-1 (BiPoD).

Institutional Review Board Statement: Not applicable.

Informed Consent Statement: Not applicable.

Data Availability Statement: Not applicable.

Conflicts of Interest: The authors declare that they have no conflict of interest.

\section{References}

1. Fisher, M.C.; Henk, D.A.; Briggs, C.J; Brownstein, J.S.; Madoff, L.C.; McCraw, S.L.; Gurr, S.J. Emerging fungal threats to animal, plant and ecosystem health. Nature 2012, 484, 186-194. [CrossRef] [PubMed]

2. Lamichhane, J.R. Bacterial diseases of crops: Elucidation of the factors that lead to differences between field and experimental infections. Adv. Agron. 2015, 134, 227-246. [CrossRef]

3. Gramaje, D.; Armengol, J. Fungal trunk pathogens in the grapevine propagation process: Potential inoculum sources, detection, identification, and management strategies. Plant Dis. 2011, 95, 1040-1055. [CrossRef] [PubMed]

4. Sicard, A.; Zeilinger, A.R.; Vanhove, M.; Schartel, T.E.; Beal, D.J.; Daugherty, M.P.; Almeida, R.P.P. Xylella fastidiosa: Insights into an emerging plant pathogen. Annu. Rev. Phytopathol. 2018, 56, 181-202. [CrossRef]

5. Vanneste, J.L. The Scientific, Economic, and Social Impacts of the New Zealand Outbreak of Bacterial Canker of Kiwifruit (Pseudomonas syringae pv. actinidiae). Annu. Rev. Phytopathol. 2017, 55, 377-399. [CrossRef]

6. Kramer, J.; Simnitt, S.; Calvin, L. Fruit and Tree Nuts Outlook: September 2020; United States Department of Agriculture: Washington, DC, USA, 2020; pp. 1-45.

7. Food, E.; Authority, S. Review of the existing maximum residue levels for copper compounds according to Article 12 of Regulation (EC) No 396/2005. EFSA J. 2018, 16, e05212. [CrossRef]

8. Arena, M.; Auteri, D.; Barmaz, S.; Bellisai, G.; Brancato, A.; Brocca, D.; Bura, L.; Byers, H.; Chiusolo, A.; Court Marques, D.; et al. Peer review of the pesticide risk assessment of the active substance copper compounds copper(I), copper(II) variants namely copper hydroxide, copper oxychloride, tribasic copper sulfate, copper(I) oxide, Bordeaux mixture. EFSA J. 2018, 16, 1-25. [CrossRef]

9. World Health Organization. Copper in Drinking-Water; World Health Organization: Geneva, Switzerland, 2004.

10. Pal, K.K.; McSpadden Gardener, B. Biological Control of Plant Pathogens. Plant Health Instr. 2006, 1-25. [CrossRef]

11. Cawoy, H.; Bettiol, W.; Fickers, P.; Ongena, M. Bacillusbased biological control of plant diseases. In Pesticides in the Modern Worldpesticides Use and Management; Stoytcheva, M., Ed.; InTech: Rijeka, Croatia, 2011; pp. 273-302. [CrossRef]

12. Köhl, J.; Kolnaar, R.; Ravensberg, W.J. Mode of action of microbial biological control agents against plant diseases: Relevance beyond efficacy. Front. Plant Sci. 2019, 10, 845. [CrossRef]

13. Veerman, C.; Pinto Correia, T.; Bastioli, C.; Biro, B.; Bouma, J.; Cienciala, E.; Emmett, B.; Frison, E.; Grand, A.; Hristov Filchew, L.; et al. Caring for Soil is Caring for Life-Ensure 75\% of Soils are Healthy by 2030 for food, People, Nature and Climate; Report of the Mission Board of Soil Health and Food; European Commission: Brussels, Belgium, 2020; p. 82.

14. Van Lenteren, J.C.; Bolckmans, K.; Köhl, J.; Ravensberg, W.J.; Urbaneja, A. Biological control using invertebrates and microorganisms: Plenty of new opportunities. BioControl 2018, 63, 39-59. [CrossRef]

15. Fravel, D.R. Commercialization and Implementation of Biocontrol. Annu. Rev. Phytopathol. 2005, 43, 337-359. [CrossRef]

16. Velivelli, S.L.S.; De Vos, P.; Kromann, P.; Declerck, S.; Prestwich, B.D. Biological control agents: From field to market, problems, and challenges. Trends Biotechnol. 2014, 32, 493-496. [CrossRef] [PubMed] 
17. Marrone, P.G. Pesticidal natural products-Status and future potential. Pest Manag. Sci. 2019, 75, 2325-2340. [CrossRef]

18. Lambert, B.; Peferoen, M. Promise of Insecticidal Bacillus thuringiensis Facts and mysteries about a successful biopesticide. Bioscience 1992, 42, 112-122. [CrossRef]

19. Ongena, M.; Jacques, P. Bacillus lipopeptides: Versatile weapons for plant disease biocontrol. Trends Microbiol. 2008, 16, 115-125. [CrossRef]

20. Stockwell, V.O.; Stack, J.P. Using Pseudomonas spp. for integrated biological control. In Proceedings of the The Nature and Application of Biocontrol Microbes III: Pseudomonas spp. Phytopathology 2007, 97, 244-249. [CrossRef] [PubMed]

21. Regulation (EC) No. 1107/2009 of the European Parliament and of the Council of 21 October 2009 Concerning the Placing of Plant Protection Products on the Market and Repealing Council Directives 79/117/EEC and 91/414/EEC. Off. J. Eur. Union 2009, 309, 1-50.

22. Frederiks, C.; Wesseler, J.H.H. A comparison of the EU and US regulatory frameworks for the active substance registration of microbial biological control agents. Pest Manag. Sci. 2019, 75, 87-103. [CrossRef] [PubMed]

23. Compant, S.; Duffy, B.; Nowak, J.; Clément, C.; Barka, E.A. Use of plant growth-promoting bacteria for biocontrol of plant diseases: Principles, mechanisms of action, and future prospects. Appl. Environ. Microbiol. 2005, 71, 4951-4959. [CrossRef]

24. Leahy, J.; Mendelsohn, M.; Kough, J.; Jones, R.; Berckes, N. Biopesticide oversight and registration at the U.S. Environmental Protection Agency. ACS Symp. Ser. 2014, 1172,3-18. [CrossRef]

25. Alabouvette, C.; Olivain, C.; Steinberg, C. Biological control of plant diseases: The European situation. Eur. J. Plant Pathol. 2006, 114, 329-341. [CrossRef]

26. Environmental Protection Agency. Bacillus subtilis MBI 600 (129082) Fact Sheet; Environmental Protection Agency: Washington, DC, USA, 1999; pp. 2-3.

27. Lilly, J. US EPA, Pesticide Product Label, Serifel, 02/11/2019; Environmental Protection Agency: Washington, DC, USA, 2019; Volume 130, ISBN 1800424930.

28. Montesinos, E. Development, registration and commercialization of microbial pesticides for plant protection. Int. Microbiol. 2003, 6, 245-252. [CrossRef]

29. Gardener, B.B.M.; Fravel, D.R. Biological Control of Plant Pathogens: Research, Commercialization, and Application in the USA. Plant Health Prog. 2002, 3, 17. [CrossRef]

30. Borriss, R. Use of Plant-Associated Bacillus Strains as Biofertilizers and Biocontrol Agents in Agriculture. In Bacteria in Agrobiology: Plant Growth Responses; Maheshwari, D.K., Ed.; Springer: Berlin/Heidelberg, Germany, 2011; pp. 41-76. ISBN 978-3-642-20331-2.

31. Hartley, C. Damping-Off in Forest Nurseries; U.S. Department of Agriculture: Washington, DC, USA, 1921; Volume 934, pp. 1-99.

32. Millard, W.A.; Taylor, C.B. Antagonism of Micro-Organisms As the Controlling Factor in the: Inhibition of Scab By GreenManuring. Ann. Appl. Biol. 1927, 14, 202-216. [CrossRef]

33. Weindling, R.; Fawcett, H.S. Experiments in the control of Rhizoctonia damping-off of citrus seedlings. Hilgardia 1936, 10, 1-16. [CrossRef]

34. Escobar, M.A.; Dandekar, A.M. Agrobacterium tumefaciens as an agent of disease. Trends Plant Sci. 2003, 8, 380-386. [CrossRef]

35. Stockwell, V.O.; Johnson, K.B.; Sugar, D.; Loper, J.E. Control of Fire Blight by Pseudomonas fluorescens A506 and Pantoea vagans C9-1 Applied as Single Strains and Mixed Inocula. Biol. Control 2010, 1, 44-46. [CrossRef] [PubMed]

36. Cook, R.J.; Rovira, A.D. The role of bacteria in the biological control of Gaeumannomyces graminis by suppressive soils. Soil Biol. Biochem. 1976, 8, 269-273. [CrossRef]

37. Kandel, S.; Joubert, P.; Doty, S. Bacterial Endophyte Colonization and Distribution within Plants. Microorganisms 2017, 5, 77. [CrossRef]

38. Köhl, J.; Postma, J.; Nicot, P.; Ruocco, M.; Blum, B. Stepwise screening of microorganisms for commercial use in biological control of plant-pathogenic fungi and bacteria. Biol. Control 2011, 57, 1-12. [CrossRef]

39. Doornbos, R.F.; Van Loon, L.C.; Bakker, P.A.H.M. Impact of root exudates and plant defense signaling on bacterial communities in the rhizosphere. A review. Agron. Sustain. Dev. 2012, 32, 227-243. [CrossRef]

40. Erlacher, A.; Cardinale, M.; Grosch, R.; Grube, M.; Berg, G. The impact of the pathogen Rhizoctonia solani and its beneficial counterpart Bacillus amyloliquefaciens on the indigenous lettuce microbiome. Front. Microbiol. 2014, 5, 175. [CrossRef]

41. Vlamakis, H.; Chai, Y.; Beauregard, P.; Losick, R.; Kolter, R. Sticking together: Building a biofilm the Bacillus subtilis way. Nat. Rev. Microbiol. 2013, 11, 157-168. [CrossRef] [PubMed]

42. Niazi, A.; Manzoor, S.; Asari, S.; Bejai, S.; Meijer, J.; Bongcam-Rudloff, E. Genome Analysis of Bacillus amyloliquefaciens Subsp. plantarum UCMB5113: A Rhizobacterium That Improves Plant Growth and Stress Management. PLoS ONE 2014, 9, e104651. [CrossRef]

43. De Jong, I.G.; Beilharz, K.; Kuipers, O.P.; Veening, J.-W. Live Cell Imaging of Bacillus subtilis and Streptococcus pneumoniae using Automated Time-lapse Microscopy. J. Vis. Exp. 2011, e3145. [CrossRef] [PubMed]

44. Angelopoulou, D.J.; Naska, E.J.; Paplomatas, E.J.; Tjamos, S.E. Biological control agents (BCAs) of verticillium wilt: Influence of application rates and delivery method on plant protection, triggering of host defence mechanisms and rhizosphere populations of BCAs. Plant Pathol. 2014, 63, 1062-1069. [CrossRef]

45. Bonaterra, A.; Cabrefiga, J.; Camps, J.; Montesinos, E. Increasing survival and efficacy of a bacterial biocontrol agent of fire blight of rosaceous plants by means of osmoadaptation. FEMS Microbiol. Ecol. 2007, 61, 185-195. [CrossRef] 
46. Lindow, S.E.; Suslow, T.V. Temporal dynamics of the biocontrol agent Pseudomonas fluorescens strain A506 in flowers in inoculated pear trees. Phytopathology 2003, 93, 727-737. [CrossRef] [PubMed]

47. Auld, B.A.; Morin, L. Constraints in the Development of Bioherbicides. Weed Technol. 1995, 9, 638-652. [CrossRef]

48. Haas, D.; Défago, G. Biological control of soil-borne pathogens by fluorescent pseudomonads. Nat. Rev. Microbiol. 2005, 3, 307-319. [CrossRef]

49. Saha, D.; Purkayastha, G.D.; Ghosh, A.; Isha, M.; Saha, A. Isolation and Characterization of Two New Bacillus Subtilis Strains From the Rhizosphere of Eggplant As Potential Biocontrol Agents. J. Plant Pathol. 2012, 94, 109-118.

50. Fan, B.; Wang, C.; Song, X.; Ding, X.; Wu, L.; Wu, H.; Gao, X.; Borriss, R. Bacillus velezensis FZB42 in 2018: The gram-positive model strain for plant growth promotion and biocontrol. Front. Microbiol. 2018, 9, 2491. [CrossRef] [PubMed]

51. Sturz, A. Bacterial root zone communities, beneficial allelopathies and plant disease control. In Allelochemical Biological Control of Plant Pathogens and Diseases; Springer: Dordrecht, The Netherlands, 2006; pp. 123-142. ISBN 9781402044458.

52. De La Fuente, L.; Quagliotto, L.; Bajsa, N.; Fabiano, E.; Altier, N.; Arias, A. Inoculation with Pseudomonas fiuorescens biocontrol strains does not affect the symbiosis between rhizobia and forage legumes. Soil Biol. Biochem. 2002, 34, 545-548. [CrossRef]

53. Velusamy, P.; Ebenezar Immanuel, J.; Gnanamanickam, S.S.; Thomashow, L. Biological control of rice bacterial blight by plantassociated bacteria producing 2,4-diacetylphloroglucinol. Can. J. Microbiol. 2006, 52, 56-65. [CrossRef]

54. Caulier, S.; Nannan, C.; Gillis, A.; Licciardi, F.; Bragard, C.; Mahillon, J. Overview of the antimicrobial compounds produced by members of the Bacillus subtilis group. Front. Microbiol. 2019, 10, 302. [CrossRef]

55. Delves-Broughton, J. Nisin and its application as a food preservative. J. Soc. Dairy Technol. 1990, 43, 73-76. [CrossRef]

56. Parisot, J.; Carey, S.; Breukink, E.; Chan, W.C.; Narbad, A.; Bonev, B. Molecular mechanism of target recognition by subtilin, a class I lanthionine antibiotic. Antimicrob. Agents Chemother. 2008, 52, 612-618. [CrossRef] [PubMed]

57. Hammami, I.; Rhouma, A.; Jaouadi, B.; Rebai, A.; Nesme, X. Optimization and biochemical characterization of a bacteriocin from a newly isolated Bacillus subtilis strain 14B for biocontrol of Agrobacterium spp. strains. Lett. Appl. Microbiol. 2009, 48, 253-260. [CrossRef] [PubMed]

58. Chen, X.H.; Scholz, R.; Borriss, M.; Junge, H.; Mögel, G.; Kunz, S.; Borriss, R. Difficidin and bacilysin produced by plant-associated Bacillus amyloliquefaciens are efficient in controlling fire blight disease. J. Biotechnol. 2009, 140, 38-44. [CrossRef]

59. Wu, L.; Wu, H.; Chen, L.; Yu, X.; Borriss, R.; Gao, X. Difficidin and bacilysin from Bacillus amyloliquefaciens FZB42 have antibacterial activity against Xanthomonas oryzae rice pathogens. Sci. Rep. 2015, 5, 12975. [CrossRef]

60. Zeriouh, H.; Romero, D.; Garcia-Gutierrez, L.; Cazorla, F.M.; de Vicente, A.; Perez-Garcia, A. The iturin-like lipopeptides are essential components in the biological control arsenal of Bacillus subtilis against bacterial diseases of cucurbits. Mol. Plant. Microbe. Interact. 2011, 24, 1540-1552. [CrossRef] [PubMed]

61. Chen, M.C.; Wang, J.P.; Zhu, Y.J.; Liu, B.; Yang, W.J.; Ruan, C.Q. Antibacterial activity against Ralstonia solanacearum of the lipopeptides secreted from the Bacillus amyloliquefaciens strain FJAT-2349. J. Appl. Microbiol. 2019, 126, 1519-1529. [CrossRef]

62. Haas, D.; Keel, C. Regulation of Antibiotic Production in Root-Colonizing Pseudomonas spp. and Relevance for Biological Control of Plant Disease. Annu. Rev. Phytopathol. 2003, 41, 117-153. [CrossRef] [PubMed]

63. Sanchez, S.; Chavez, A.; Forero, A.; Garcia-Huante, Y.; Romero, A.; Sanchez, M.; Rocha, D.; Sanchez, B.; Avalos, M.; GuzmanTrampe, S.; et al. Carbon source regulation of antibiotic production. J. Antibiot. 2010, 63, 442-459. [CrossRef]

64. Jacques, P. Biosurfactants: From Genes to Applications; Soberon-Chavez, G., Ed.; Springer: Berlin/Heidelberg, Germany, 2011; pp. 57-91. ISBN 9783642144899.

65. Duffy, B.K.; Défago, G. Environmental factors modulating antibiotic and siderophore biosynthesis by Pseudomonas fluorescens biocontrol strains. Appl. Environ. Microbiol. 1999, 65, 2429-2438. [CrossRef] [PubMed]

66. Milner, J.L.; Silo-Suh, L.; Lee, J.C.; Haiyin, H.E.; Clardy, J.; Handelsman, J.O. Production of kanosamine by Bacillus cereus UW85. Appl. Environ. Microbiol. 1996, 62, 3061-3065. [CrossRef]

67. Lugtenberg, B.; Rozen, D.E.; Kamilova, F. Wars between microbes on roots and fruits. F1000Research 2017, 6, 343. [CrossRef]

68. Garbeva, P.; Silby, M.W.; Raaijmakers, J.M.; Levy, S.B.; Boer, W. De Transcriptional and antagonistic responses of Pseudomonas fluorescens Pf0-1 to phylogenetically different bacterial competitors. ISME J. 2011, 5, 973-985. [CrossRef] [PubMed]

69. Traxler, M.F.; Watrous, J.D.; Alexandrov, T.; Dorrestein, P.C.; Kolter, R. Interspecies Interactions Stimulate Diversification of the Streptomyces coelicolor Secreted Metabolome. MBio 2013, 4, e00459-13. [CrossRef]

70. Tyc, O.; van den Berg, M.; Gerards, S.; van Veen, J.A.; Raaijmakers, J.M.; de Boer, W.; Garbeva, P. Impact of interspecific interactions on antimicrobial activity among soil bacteria. Front. Microbiol. 2014, 5, 567. [CrossRef]

71. Raaijmakers, J.M.; Mazzola, M. Diversity and Natural Functions of Antibiotics Produced by Beneficial and Plant Pathogenic Bacteria. Annu. Rev. Phytopathol. 2012, 50, 403-424. [CrossRef]

72. Koch, E.; Becker, J.; Berg, G.; Hauschild, R.; Jehle, J.; Kohl, J.; Smalla, K. Biocontrol of plant diseases is not an unsafe technology! J. Plant Dis. Prot. 2018, 125, 121-125. [CrossRef]

73. Dimopoulou, A.; Theologidis, I.; Benaki, D.; Koukounia, M.; Zervakou, A.; Tzima, A.; Diallinas, G.; Hatzinikolaou, D.G.; Skandalis, N. Direct Antibiotic Activity of Bacillibactin Broadens the Biocontrol Range of Bacillus amyloliquefaciens MBI600. mSphere 2021, 6, e00376-21. [CrossRef] [PubMed]

74. Quadri, L.E.N. MicroReview Assembly of aryl-capped siderophores by modular peptide synthetases and polyketide synthases. Mol. Microbiol. 2000, 37, 1-12. [CrossRef] 
75. Su, C.; Zhang, M.; Lin, L.; Yu, G.; Zhong, H.; Chong, Y. Reduction of iron oxides and microbial community composition in iron-rich soils with different organic carbon as electron donors. Int. Biodeterior. Biodegradation 2020, 148, 104881. [CrossRef]

76. Winkelmann, G. Ecology of siderophores with special reference to the fungi. BioMetals 2007, 20, 379-392. [CrossRef]

77. Sullivan, T.S.; Ramkissoon, S.; Garrison, V.H.; Ramsubhag, A.; Thies, J.E. Siderophore production of African dust microorganisms over Trinidad and Tobago. Aerobiologia 2012, 28, 391-401. [CrossRef]

78. Masalha, J.; Kosegarten, H.; Elmaci, Ö. The central role of microbial activity for iron acquisition in maize and sunflower. Biol Fertil Soils 2000, 433-439. [CrossRef]

79. Greenshields, D.L.; Liu, G.; Feng, J.; Selvaraj, G.; Wei, Y. The siderophore biosynthetic gene SID1, but not the ferroxidase gene FET3, is required for full Fusarium graminearum virulence. Mol. Plant Pathol. 2007, 8, 411-421. [CrossRef] [PubMed]

80. Heymann, P.; Ernst, J.F.; Winkelmann, G. A gene of the major facilitator superfamily encodes a transporter for enterobactin (Enb1p) in Saccharomyces cerevisiae. BioMetals 2000, 13, 65-72. [CrossRef]

81. Arias, A.A.; Lambert, S.; Martinet, L.; Adam, D.; Tenconi, E.; Hayette, M.P.; Ongena, M.; Rigali, S. Growth of desferrioxaminedeficient Streptomyces mutants through xenosiderophore piracy of airborne fungal contaminations. FEMS Microbiol. Ecol. 2015, 91, fiv080. [CrossRef]

82. Kloepper, J.W.; Leong, J.; Teintze, M.; Schroth, M.N. Enhanced plant growth by siderophores produced by plant growth-promoting rhizobacteria. Nature 1980, 286, 885-886. [CrossRef]

83. Huang, Y.; Jiang, Y.; Wang, H.; Wang, J.; Cheol, M.; Byun, Y.; He, H.; Liang, Y.; Yang, V.C. Curb challenges of the "Trojan Horse" approach: Smart strategies in achieving effective yet safe cell-penetrating peptide-based drug delivery. Adv. Drug Deliv. Rev. 2013, 65, 1299-1315. [CrossRef] [PubMed]

84. Mendes, R.; Garbeva, P.; Raaijmakers, J.M. The rhizosphere microbiome: Significance of plant beneficial, plant pathogenic, and human pathogenic microorganisms. FEMS Microbiol. Rev. 2013, 37, 634-663. [CrossRef]

85. Finkel, O.M.; Castrillo, G.; Herrera Paredes, S.; Salas González, I.; Dangl, J.L. Understanding and exploiting plant beneficial microbes. Curr. Opin. Plant Biol. 2017, 38, 155-163. [CrossRef]

86. Naylor, D.; Coleman-Derr, D. Drought Stress and Root-Associated Bacterial Communities. Front. Plant Sci. $2018,8,2223$. [CrossRef]

87. Wang, R.; Zhang, H.; Sun, L.; Qi, G.; Chen, S.; Zhao, X. Microbial community composition is related to soil biological and chemical properties and bacterial wilt outbreak. Sci. Rep. 2017, 7, 343. [CrossRef]

88. Badri, D.V.; Weir, T.L.; van der Lelie, D.; Vivanco, J.M. Rhizosphere chemical dialogues: Plant-microbe interactions. Curr. Opin. Biotechnol. 2009, 20, 642-650. [CrossRef]

89. Berg, G.; Grube, M.; Schloter, M.; Smalla, K. Unraveling the plant microbiome: Looking back and future perspectives. Front. Microbiol. 2014, 5, 148. [CrossRef] [PubMed]

90. Feng, H.; Zhang, N.; Du, W.; Zhang, H.; Liu, Y.; Fu, R.; Shao, J.; Zhang, G.; Shen, Q.; Zhang, R. Identification of chemotaxis compounds in root exudates and their sensing chemoreceptors in plant-growth-promoting rhizobacteria bacillus amyloliquefaciens SQR9. Mol. Plant-Microbe Interact. 2018, 31, 995-1005. [CrossRef]

91. el Zahar Haichar, F.; Santaella, C.; Heulin, T.; Achouak, W. Root exudates mediated interactions belowground. Soil Biol. Biochem. 2014, 77, 69-80. [CrossRef]

92. Backer, R.; Rokem, J.S.; Ilangumaran, G.; Lamont, J.; Praslickova, D.; Ricci, E.; Subramanian, S.; Smith, D.L. Plant growthpromoting rhizobacteria: Context, mechanisms of action, and roadmap to commercialization of biostimulants for sustainable agriculture. Front. Plant Sci. 2018, 9, 1473. [CrossRef]

93. Mhlongo, M.I.; Piater, L.A.; Madala, N.E.; Labuschagne, N.; Dubery, I.A. The Chemistry of Plant-Microbe Interactions in the Rhizosphere and the Potential for Metabolomics to Reveal Signaling Related to Defense Priming and Induced Systemic Resistance. Front. Plant Sci. 2018, 9, 112. [CrossRef] [PubMed]

94. Van Loon, L.C. Plant responses to plant growth-promoting rhizobacteria. In New Perspectives and Approaches in Plant GrowthPromoting Rhizobacteria Research; Springer: Dordrecht, The Netherlands, 2007; pp. 243-254.

95. Fan, B.; Borriss, R.; Bleiss, W.; Wu, X. Gram-positive rhizobacterium Bacillus amyloliquefaciens FZB42 colonizes three types of plants in different patterns. J. Microbiol. 2012, 50, 38-44. [CrossRef] [PubMed]

96. Chowdhury, S.P.; Hartmann, A.; Gao, X.W.; Borriss, R. Biocontrol mechanism by root-associated Bacillus amyloliquefaciens FZB42-A review. Front. Microbiol. 2015, 6, 780. [CrossRef] [PubMed]

97. Dietel, K.; Beator, B.; Budiharjo, A.; Fan, B.; Borriss, R. Bacterial Traits Involved in colonization of Arabidopsis thaliana roots by Bacillus amyloliquefaciens FZB42. Plant Pathol. J. 2013, 29, 59. [CrossRef]

98. Liu, Y.; Feng, H.; Chen, L.; Zhang, H.; Dong, X.; Xiong, Q.; Zhang, R. Root-Secreted Spermine Binds to Bacillus amyloliquefaciens SQR9 Histidine Kinase KinD and Modulates Biofilm Formation. Mol. Plant-Microbe Interact. 2020, 33, 423-432. [CrossRef] [PubMed]

99. Calvio, C.; Celandroni, F.; Ghelardi, E.; Amati, G.; Salvetti, S.; Ceciliani, F.; Galizzi, A.; Senesi, S. Swarming differentiation and swimming motility in Bacillus subtilis are controlled by swrA, a newly identified dicistronic operon. J. Bacteriol. 2005, 187, 5356-5366. [CrossRef] [PubMed]

100. Bulgarelli, D.; Schlaeppi, K.; Spaepen, S.; van Themaat, E.V.L.; Schulze-Lefert, P. Structure and Functions of the Bacterial Microbiota of Plants. Annu. Rev. Plant Biol. 2013, 64, 807-838. [CrossRef] 
101. Bringel, F.; Couée, I. Pivotal roles of phyllosphere microorganisms at the interface between plant functioning and atmospheric trace gas dynamics. Front. Microbiol. 2015, 6, 486. [CrossRef]

102. Thapa, S.; Prasanna, R.; Ranjan, K.; Velmourougane, K.; Ramakrishnan, B. Nutrients and host attributes modulate the abundance and functional traits of phyllosphere microbiome in rice. Microbiol. Res. 2017, 204, 55-64. [CrossRef]

103. Skandalis, N.; Sarris, P.F.; Panopoulos, N.J. Targeting injectisomes of virulence: Benefits of thirty years of research on bacterial secretion systems, to crop protection. Hell. Plant Prot. J. 2012, 5, 31-47. Available online: https://www.bpi.gr/files/journal/2012 /july/Hellenic\%20Plant\%20Protection\%20Journal\%20-\%20Skandalis\%20(July\%202012).indd.pdf (accessed on 4 July 2021).

104. Spoel, S.H.; Dong, X. How do plants achieve immunity? Defence without specialized immune cells. Nat. Rev. Immunol. 2012, 12, 89-100. [CrossRef] [PubMed]

105. Pieterse, C.M.J.; Van der Does, D.; Zamioudis, C.; Leon-Reyes, A.; Van Wees, S.C.M. Hormonal Modulation of Plant Immunity. Annu. Rev. Cell Dev. Biol. 2012, 28, 489-521. [CrossRef]

106. Beckers, G.J.M.; Conrath, U. Priming for stress resistance: From the lab to the field. Curr. Opin. Plant Biol. 2007, 10, 425-431. [CrossRef] [PubMed]

107. Van Wees, S.C.; Van der Ent, S.; Pieterse, C.M. Plant immune responses triggered by beneficial microbes. Curr. Opin. Plant Biol. 2008, 11, 443-448. [CrossRef]

108. Spoel, S.H. NPR1 Modulates Cross-Talk between Salicylate- and Jasmonate-Dependent Defense Pathways through a Novel Function in the Cytosol. Plant Cell Online 2003, 15, 760-770. [CrossRef]

109. Kunkel, B.N.; Brooks, D.M. Cross talk between signaling pathways in pathogen defense. Curr. Opin. Plant Biol. $2002,5,325-331$. [CrossRef]

110. Chowdhury, S.P.; Uhl, J.; Grosch, R.; Alqu, S.; Pittroff, S.; Dietel, K.; Schmitt-Kopplin, P.; Borriss, R.; Hartmann, A. Cyclic Lipopeptides of Bacillus amyloliquefaciens subsp. plantarum Colonizing the Lettuce Rhizosphere Enhance Plant Defense Responses Toward the Bottom Rot Pathogen Rhizoctonia solani. Mol. Plant-Microbe Interact. 2015, 28, 984-995. [CrossRef]

111. Dimopoulou, A.; Theologidis, I.; Liebmann, B.; Kalantidis, K.; Vassilakos, N.; Skandalis, N. Bacillus amyloliquefaciens MBI600 differentially induces tomato defense signaling pathways depending on plant part and dose of application. Sci. Rep. 2019, 9, 19120. [CrossRef]

112. Beris, D.; Theologidis, I.; Skandalis Nicholasand Vassilakos, N. Bacillus amyloliquefaciens strain MBI600 induces salicylic aciddependent resistance in tomato plants against Tomato spotted wiltvirus and Potato virus Y. Sci. Rep. 2018, 8, 10320. [CrossRef] [PubMed]

113. Ryu, C.-M.; Murphy, J.F.; Mysore, K.S.; Kloepper, J.W. Plant growth-promoting rhizobacteria systemically protect Arabidopsis thaliana against Cucumber mosaic virus by a salicylic acid and NPR1-independent and jasmonic acid-dependent signaling pathway. Plant J. 2004, 39, 381-392. [CrossRef]

114. Kloepper, J.W.; Ryu, C.; Zhang, S. Induced Systemic Resistance and Promotion of Plant Growth by Bacillus spp. Phytopathology 2004, 94, 1259-1266. [CrossRef] [PubMed]

115. Fousia, S.; Paplomatas, E.J.; Tjamos, S.E. Bacillus subtilis QST 713 Confers Protection to Tomato Plants Against Pseudomonas syringae pv tomato and Induces Plant Defence-related Genes. J. Phytopathol. 2016, 164, 264-270. [CrossRef]

116. Raaijmakers, J.M.; De Bruijn, I.; Nybroe, O.; Ongena, M. Natural functions of lipopeptides from Bacillus and Pseudomonas: More than surfactants and antibiotics. FEMS Microbiol. Rev. 2010, 34, 1037-1062. [CrossRef] [PubMed]

117. Wu, G.; Liu, Y.; Xu, Y.; Zhang, G.; Shen, Q.; Zhang, R. Exploring elicitors of the beneficial rhizobacterium Bacillus amyloliquefaciens SQR9 to induce plant systemic resistance and their interactions with plant signaling pathways. Mol. Plant-Microbe Interact. 2018, 31, 560-567. [CrossRef]

118. Beris, D.; Vassilakos, N. Plant beneficial microbes: Do they have a role as antiviral agents in agriculture? Mol. Asp. Plant Benef. Microbes Agric. 2020, 19-33. [CrossRef]

119. Brown, L.; Kessler, A.; Cabezas-Sanchez, P.; Luque-Garcia, J.L.; Casadevall, A. Extracellular vesicles produced by the Grampositive bacterium Bacillus subtilis are disrupted by the lipopeptide surfactin. Mol. Microbiol. 2014, 93, 183-198. [CrossRef]

120. Pangesti, N.; Reichelt, M.; van de Mortel, J.E.; Kapsomenou, E.; Gershenzon, J.; van Loon, J.J.A.; Dicke, M.; Pineda, A. Jasmonic Acid and Ethylene Signaling Pathways Regulate Glucosinolate Levels in Plants During Rhizobacteria-Induced Systemic Resistance Against a Leaf-Chewing Herbivore. J. Chem. Ecol. 2016, 42, 1212-1225. [CrossRef]

121. Zebelo, S.; Song, Y.; Kloepper, J.W.; Fadamiro, H. Rhizobacteria activates (+)- $\delta$-cadinene synthase genes and induces systemic resistance in cotton against beet armyworm (Spodoptera exigua). Plant Cell Environ. 2016, 39, 935-943. [CrossRef]

122. Sharma, R.R.; Singh, D.; Singh, R. Biological control of postharvest diseases of fruits and vegetables by microbial antagonists: A review. Biol. Control 2009, 50, 205-221. [CrossRef]

123. Acero, J.L.; Benítez, F.J.; Real, F.J.; González, M. Chlorination of organophosphorus pesticides in natural waters. J. Hazard. Mater. 2008, 153, 320-328. [CrossRef]

124. Kole, R.K.; Banerjee, H.; Bhattacharyya, A. Monitoring of market fish samples for endosulfan and hexachlorocyclohexane residues in and around Calcutta. Bull. Environ. Contam. Toxicol. 2001, 67, 554-559. [CrossRef] [PubMed]

125. Santos, A.; Flores, M. Effects of glyphosate on nitrogen fixation of free-living heterotrophic bacteria. Lett. Appl. Microbiol. 1995, 20, 349-352. [CrossRef]

126. Arias, R.N.; Fabra de Peretti, A. Effects of 2,4-dichlorophenoxyacetic acid on Rhizobium sp. growth and characterization of its transport. Toxicol. Lett. 1993, 68, 267-273. [CrossRef] 
127. Fabra, A.; Duffard, R.; Evangelista De Duffard, A. Toxicity of 2,4-dichlorophenoxyacetic acid to Rhizobium sp. in pure culture. Bull. Environ. Contam. Toxicol. 1997, 59, 645-652. [CrossRef] [PubMed]

128. Folmar, L.C.; Sanders, H.O.; Julin, A.M. Toxicity of the herbicide glyphosate and several of its formulations to fish and aquatic invertebrates. Arch. Environ. Contam. Toxicol. 1979, 8, 269-278. [CrossRef]

129. Gadeva, P.; Dimitrov, B. Genotoxic effects of the pesticides Rubigan, Omite and Rovral in root-meristem cells of Crepis capillaris L. Mutat. Res.-Genet. Toxicol. Environ. Mutagen. 2008, 652, 191-197. [CrossRef] [PubMed]

130. Igbedioh, S.O. Effects of agricultural pesticides on humans, animals, and higher plants in developing countries. Arch. Environ. Health 1991, 46, 218-224. [CrossRef] [PubMed]

131. Brouwer, A.; Longnecker, M.P.; Birnbaum, L.S.; Cogliano, J.; Kostyniak, P.; Moore, J.; Schantz, S.; Winneke, G. Characterization of potential endocrine-related health effects at low-dose levels of exposure to PCBs. Environ. Health Perspect. 1999, 107, 639-649. [CrossRef]

132. Crisp, T.M.; Clegg, E.D.; Cooper, R.L.; Wood, W.P.; Andersen, D.G.; Baetcke, K.P.; Hoffmann, J.L.; Morrow, M.S.; Rodier, D.J.; Schaeffer, J.E.; et al. Environmental endocrine disruption: An effects assessment and analysis. Environ. Health Perspect. 1998, 106, 11-56. [PubMed]

133. Berlec, A. Novel techniques and findings in the study of plant microbiota: Search for plant probiotics. Plant Sci. 2012, 193-194, 96-102. [CrossRef]

134. Jiménez, J.A.; Novinscak, A.; Filion, M. Inoculation with the Plant-Growth-Promoting Rhizobacterium Pseudomonas fluorescens LBUM677 Impacts the Rhizosphere Microbiome of Three Oilseed Crops. Front. Microbiol. 2020, 11, 2534. [CrossRef] [PubMed]

135. Grosch, R.; Dealtry, S.; Schreiter, S.; Berg, G.; Mendonça-Hagler, L.; Smalla, K. Biocontrol of Rhizoctonia solani: Complex interaction of biocontrol strains, pathogen and indigenous microbial community in the rhizosphere of lettuce shown by molecular methods. Plant Soil 2012, 361, 343-357. [CrossRef]

136. Chowdhury, S.P.; Dietel, K.; Rändler, M.; Schmid, M.; Junge, H.; Borriss, R.; Hartmann, A.; Grosch, R. Effects of Bacillus amyloliquefaciens FZB42 on Lettuce Growth and Health under Pathogen Pressure and Its Impact on the Rhizosphere Bacterial Community. PLoS ONE 2013, 8, e68818. [CrossRef]

137. Scherwinski, K.; Wolf, A.; Berg, G. Assessing the risk of biological control agents on the indigenous microbial communities: Serratia plymuthica HRO-C48 and Streptomyces sp. HRO-71 as model bacteria. BioControl 2007, 52, 87-112. [CrossRef]

138. Sang, M.K.; Kim, K.D. Plant growth-promoting rhizobacteria suppressive to Phytophthora blight affect microbial activities and communities in the rhizosphere of pepper (Capsicum annuum L.) in the field. Appl. Soil Ecol. 2012, 62, 88-97. [CrossRef]

139. Chen, Y.; Yan, F.; Chai, Y.; Liu, H.; Kolter, R.; Losick, R.; Guo, J.H. Biocontrol of tomato wilt disease by Bacillus subtilis isolates from natural environments depends on conserved genes mediating biofilm formation. Environ. Microbiol. 2013, 15, 848-864. [CrossRef] [PubMed]

140. Yin, D.; Wang, N.; Xia, F.; Li, Q.; Wang, W. Impact of biocontrol agents Pseudomonas fluorescens 2 P24 and CPF10 on the bacterial community in the cucumber rhizosphere. Eur. J. Soil Biol. 2013, 59, 36-42. [CrossRef]

141. Kröber, M.; Wibberg, D.; Grosch, R.; Eikmeyer, F.; Verwaaijen, B.; Chowdhury, S.P.; Hartmann, A.; Pühler, A.; Schlüter, A. Effect of the strain Bacillus amyloliquefaciens FZB42 on the microbial community in the rhizosphere of lettuce under field conditions analyzed by whole metagenome sequencing. Front. Microbiol. 2014, 5, 252. [CrossRef]

142. Perazzolli, M.; Antonielli, L.; Storari, M.; Puopolo, G.; Pancher, M.; Giovannini, O.; Pindo, M.; Pertot, I. Resilience of the natural phyllosphere microbiota of the grapevine to chemical and biological pesticides. Appl. Environ. Microbiol. 2014, 80, 3585-3596. [CrossRef] [PubMed]

143. Schreiter, S.; Ding, G.-C.; Grosch, R.; Kropf, S.; Antweiler, K.; Smalla, K. Soil type-dependent effects of a potential biocontrol inoculant on indigenous bacterial communities in the rhizosphere of field-grown lettuce. FEMS Microbiol. Ecol. 2014, 90, 718-730 [CrossRef] [PubMed]

144. Sylla, J.; Alsanius, B.W.; Krüger, E.; Reineke, A.; Strohmeier, S.; Wohanka, W. Leaf microbiota of strawberries as affected by biological control agents. Phytopathology 2013, 103, 1001-1011. [CrossRef]

145. Wei, F.; Hu, X.; Xu, X. Dispersal of Bacillus subtilis and its effect on strawberry phyllosphere microbiota under open field and protection conditions. Sci. Rep. 2016, 6, 22611. [CrossRef]

146. Qin, C.; Tao, J.; Liu, T.; Liu, Y.; Xiao, N.; Li, T.; Gu, Y.; Yin, H.; Meng, D. Responses of phyllosphere microbiota and plant health to application of two different biocontrol agents. AMB Express 2019, 9, 42. [CrossRef]

147. Favilla, M.; Macchia, L.; Gallo, A.; Altomare, C. Toxicity assessment of metabolites of fungal biocontrol agents using two different (Artemia salina and Daphnia magna) invertebrate bioassays. Food Chem. Toxicol. 2006, 44, 1922-1931. [CrossRef] [PubMed]

148. Grandlic, C.J.; Green, W.A.; Kenovuo, J.S.; McCann, R. Compositions and Methods for Controlling Head Blight Disease. U.S. Patent MX368976B, 23 October 2019.

149. Chen, F.; Wang, M.; Zheng, Y.; Li, S.; Wang, H.; Han, D.; Guo, S. The effect of biocontrol bacteria on rhizosphere bacterial communities analyzed by plating and pcr-dgge. Curr. Microbiol. 2013, 67, 177-182. [CrossRef] [PubMed]

150. Weng, J.; Wang, Y.; Li, J.; Shen, Q.; Zhang, R. Enhanced root colonization and biocontrol activity of Bacillus amyloliquefaciens SQR9 by abrB gene disruption. Appl. Microbiol. Biotechnol. 2013, 97, 8823-8830. [CrossRef] [PubMed]

151. Schmidt, C.S.; Agostini, F.; Leifert, C.; Killham, K.; Mullins, C.E. Influence of Soil Temperature and Matric Potential on Sugar Beet Seedling Colonization and Suppression of Pythium Damping-Off by the Antagonistic Bacteria Pseudomonas fluorescens and Bacillus subtilis. Phytopathology 2004, 94, 351-363. [CrossRef] 
152. Samaras, A.; Nikolaidis, M.; Antequera-Gómez, M.L.; Cámara-Almirón, J.; Romero, D.; Moschakis, T.; Amoutzias, G.D.; Karaoglanidis, G.S. Whole Genome Sequencing and Root Colonization Studies Reveal Novel Insights in the Biocontrol Potential and Growth Promotion by Bacillus subtilis MBI 600 on Cucumber. Front. Microbiol. 2021, 11, 600393. [CrossRef] [PubMed]

153. Williams, T.R.; Marco, M.L. Phyllosphere Microbiota Composition and Microbial Community Transplantation on Lettuce Plants Grown Indoors Thomas. MBio 2014, 5, e01564-14. [CrossRef] [PubMed]

154. Dong, C.J.; Wang, L.L.; Li, Q.; Shang, Q.M. Bacterial communities in the rhizosphere, phyllosphere and endosphere of tomato plants. PLoS ONE 2019, 14, e0223847. [CrossRef]

155. Pusey, P.L.; Stockwell, V.O.; Mazzola, M. Epiphytic Bacteria and Yeasts on Apple Blossoms and Their Potential as Antagonists of Erwinia amylovora. Phytopathology 2009, 99, 571-581. [CrossRef]

156. Escalante, A.E.; Barbolla, L.J.; Ramírez-Barahona, S.; Eguiarte, L.E. The study of biodiversity in the era of massive sequencing. Rev. Mex. Biodivers. 2014, 85, 1249-1264. [CrossRef]

157. Land, M.; Hauser, L.; Jun, S.R.; Nookaew, I.; Leuze, M.R.; Ahn, T.H.; Karpinets, T.; Lund, O.; Kora, G.; Wassenaar, T.; et al. Insights from 20 years of bacterial genome sequencing. Funct. Integr. Genomics 2015, 15, 141-161. [CrossRef] [PubMed]

158. Zhang, N.; Yang, D.; Wang, D.; Miao, Y.; Shao, J.; Zhou, X.; Xu, Z.; Li, Q.; Feng, H.; Li, S.; et al. Whole transcriptomic analysis of the plant-beneficial rhizobacterium Bacillus amyloliquefaciens SQR9 during enhanced biofilm formation regulated by maize root exudates. BMC Genom. 2015, 16, 685. [CrossRef] [PubMed]

159. Sarker, M.; Chopra, S.; Mortelmans, K.; Kodukula, K.; Talcott, C.; Galande, A.K. In Silico Pathway Analysis Predicts Metabolites that are Potential Antimicrobial Targets. J. Comput. Sci. Syst. Biol. 2011, 04, 20-26. [CrossRef]

160. Padilla-González, G.F.; Frey, M.; Gómez-Zeledón, J.; Da Costa, F.B.; Spring, O. Metabolomic and gene expression approaches reveal the developmental and environmental regulation of the secondary metabolism of yacón (Smallanthus sonchifolius, Asteraceae). Sci. Rep. 2019, 9, 13178. [CrossRef]

161. Covington, B.C.; McLean, J.A.; Bachmann, B.O. Comparative mass spectrometry-based metabolomics strategies for the investigation of microbial secondary metabolites. Nat. Prod. Rep. 2017, 34, 6-24. [CrossRef] [PubMed]

162. Bulgarelli, D.; Garrido-Oter, R.; Münch, P.C.; Weiman, A.; Dröge, J.; Pan, Y.; McHardy, A.C.; Schulze-Lefert, P. Structure and function of the bacterial root microbiota in wild and domesticated barley. Cell Host Microbe 2015, 17, 392-403. [CrossRef]

163. Wielkopolan, B.; Obrępalska-Stęplowska, A. Three-way interaction among plants, bacteria, and coleopteran insects. Planta 2016, 244, 313-332. [CrossRef]

164. Humphrey, P.T.; Whiteman, N.K. Insect herbivory reshapes a native leaf microbiome. Nat. Ecol. Evol. 2020, 4, 221-229. [CrossRef] [PubMed]

165. Gupta, A.; Nair, S. Dynamics of Insect-Microbiome Interaction Influence Host and Microbial Symbiont. Front. Microbiol. 2020, 11, 1357. [CrossRef]

166. Sugio, A.; Dubreuil, G.; Giron, D.; Simon, J.C. Plant-insect interactions under bacterial influence: Ecological implications and underlying mechanisms. J. Exp. Bot. 2015, 66, 467-478. [CrossRef]

167. Tiwari, S.; Prasad, V.; Chauhan, P.S.; Lata, C. Bacillus amyloliquefaciens Confers Tolerance to Various Abiotic Stresses and Modulates Plant Response to Phytohormones through Osmoprotection and Gene Expression Regulation in Rice. Front. Plant Sci. 2017, 8, 1510. [CrossRef] [PubMed]

168. Dutta, S.; Khurana, S.M.P. Plant Growth-Promoting Rhizobacteria for Alleviating Abiotic Stresses in Medicinal Plants; Springer: Cham, Switzerland, 2015; pp. 167-200.

169. Numan, M.; Bashir, S.; Khan, Y.; Mumtaz, R.; Shinwari, Z.K.; Khan, A.L.; Khan, A.; AL-Harrasi, A. Plant growth promoting bacteria as an alternative strategy for salt tolerance in plants: A review. Microbiol. Res. 2018, 209, 21-32. [CrossRef] [PubMed]

170. Chen, L.; Liu, Y.; Wu, G.; Zhang, N.; Shen, Q.; Zhang, R. Beneficial Rhizobacterium bacillus amyloliquefaciens SQR9 induces plant salt tolerance through spermidine production. Mol. Plant-Microbe Interact. 2017, 30, 423-432. [CrossRef]

171. Prudent, M.; Salon, C.; Souleimanov, A.; Emery, R.J.N.; Smith, D.L. Soybean is less impacted by water stress using Bradyrhizobium japonicum and thuricin-17 from Bacillus thuringiensis. Agron. Sustain. Dev. 2015, 35, 749-757. [CrossRef]

172. Köberl, M.; Müller, H.; Ramadan, E.M.; Berg, G. Desert farming benefits from microbial potential in arid soils and promotes diversity and plant health. PLoS ONE 2011, 6, e24452. [CrossRef]

173. Etesami, H.; Mirseyed Hosseini, H.; Alikhani, H.A. Bacterial biosynthesis of 1-aminocyclopropane-1-caboxylate (ACC) deaminase, a useful trait to elongation and endophytic colonization of the roots of rice under constant flooded conditions. Physiol. Mol. Biol. Plants 2014, 20, 425-434. [CrossRef] [PubMed]

174. Habib, S.H.; Kausar, H.; Saud, H.M. Plant Growth-Promoting Rhizobacteria Enhance Salinity Stress Tolerance in Okra through ROS-Scavenging Enzymes. BioMed Res. Int. 2016, 2016, 6284547. [CrossRef]

175. Kang, S.M.; Khan, A.L.; Waqas, M.; You, Y.H.; Hamayun, M.; Joo, G.J.; Shahzad, R.; Choi, K.S.; Lee, I.J. Gibberellin-producing Serratia nematodiphila PEJ1011 ameliorates low temperature stress in Capsicum annuum L. Eur. J. Soil Biol. 2015, 68, 85-93. [CrossRef]

176. Fernandez, O.; Theocharis, A.; Bordiec, S.; Feil, R.; Jacquens, L.; Clément, C.; Fontaine, F.; Barka, E.A. Burkholderia phytofirmans PsJN acclimates grapevine to cold by modulating carbohydrate metabolism. Mol. Plant-Microbe Interact. 2012, 25, 496-504. [CrossRef]

177. Slininger, P.J.; Schisler, D.A.; Ericsson, L.D.; Brandt, T.L.; Frazier, M.J.; Woodell, L.K.; Olsen, N.L.; Kleinkopf, G.E. Biological control of post-harvest late blight of potatoes. Biocontrol Sci. Technol. 2007, 17, 647-663. [CrossRef] 
178. Raupach, G.S.; Kloepper, J.W. Mixtures of plant growth-promoting rhizobacteria enhance biological control of multiple cucumber pathogens. Phytopathology 1998, 88, 1158-1164. [CrossRef] [PubMed]

179. Roberts, D.P.; Lohrke, S.M.; Meyer, S.L.F.; Buyer, J.S.; Bowers, J.H.; Baker, C.J.; Li, W.; De Souza, J.T.; Lewis, J.A.; Chung, S. Biocontrol agents applied individually and in combination for suppression of soilborne diseases of cucumber. Crop Prot. 2005, 24, 141-155. [CrossRef]

180. Muthukumar, A.; Eswaran, A.; Sangeetha, G. Induction of systemic resistance by mixtures of fungal and endophytic bacterial isolates against Pythium aphanidermatum. Acta Physiol. Plant. 2011, 33, 1933-1944. [CrossRef]

181. Gyenis, L.; Anderson, N.A.; Ostry, M.E. Biological control of Septoria leaf spot disease of hybrid poplar in the field. Plant Dis. 2003, 87, 809-813. [CrossRef]

182. Xu, X.M.; Jeffries, P.; Pautasso, M.; Jeger, M.J. Combined use of biocontrol agents to manage plant diseases in theory and practice. Phytopathology 2011, 101, 1024-1031. [CrossRef]

183. Izquierdo-García, L.F.; González-Almario, A.; Cotes, A.M.; Moreno-Velandia, C.A. Trichoderma virens Gl006 and Bacillus velezensis Bs006: A compatible interaction controlling Fusarium wilt of cape gooseberry. Sci. Rep. 2020, 10, 6857. [CrossRef]

184. Ayoubi, N.; Zafari, D.; Mirabolfathy, M. Evaluation of $\beta-1,3$-glucanase and $\beta-1,4$-glucanase enzymes production in some Trichoderma species. Arch. Phytopathol. Plant Prot. 2014, 47, 1929-1941. [CrossRef]

185. Poveda, J.; Hermosa, R.; Monte, E.; Nicolás, C. Trichoderma harzianum favours the access of arbuscular mycorrhizal fungi to non-host Brassicaceae roots and increases plant productivity. Sci. Rep. 2019, 9, 11650. [CrossRef] [PubMed]

186. Wu, C.H.; Bernard, S.M.; Andersen, G.L.; Chen, W. Developing microbe-plant interactions for applications in plant-growth promotion and disease control, production of useful compounds, remediation and carbon sequestration. Microb. Biotechnol. 2009, 2, 428-440. [CrossRef]

187. Gera Hol, W.H.; Martijn Bezemer, T.; Biere, A. Getting the ecology into interactions between plants and the plant growthpromoting bacterium Pseudomonas fluorescens. Front. Plant Sci. 2013, 4, 1-9. [CrossRef]

188. Aloo, B.N.; Makumba, B.A.; Mbega, E.R. The potential of Bacilli rhizobacteria for sustainable crop production and environmental sustainability. Microbiol. Res. 2019, 219, 26-39. [CrossRef]

189. Strobel, G. The emergence of endophytic microbes and their biological promise. J. Fungi 2018, 4, 57. [CrossRef] [PubMed]

190. Hardoim, P.R.; van Overbeek, L.S.; Berg, G.; Pirttilä, A.M.; Compant, S.; Campisano, A.; Döring, M.; Sessitsch, A. The Hidden World within Plants: Ecological and Evolutionary Considerations for Defining Functioning of Microbial Endophytes. Microbiol. Mol. Biol. Rev. 2015, 79, 293-320. [CrossRef]

191. Muthukumar, A.; Udhayakumar, R.; Naveenkumar, R. Role of Bacterial Endophytes in Plant Disease Control; Springer: Cham, Switzerland, 2017; pp. 133-161. [CrossRef]

192. Le Cocq, K.; Gurr, S.J.; Hirsch, P.R.; Mauchline, T.H. Exploitation of endophytes for sustainable agricultural intensification. Mol. Plant Pathol. 2017, 18, 469-473. [CrossRef]

193. Callaghan, M.O. Microbial inoculation of seed for improved crop performance: Issues and opportunities. Appl. Microbiol. Biotechnol. 2016, 100, 5729-5746. [CrossRef] [PubMed]

194. Hogervorst, P.A.M.; van den Akker, H.C.M.; Glandorf, D.C.M.; Klaassen, P.; van der Vlugt, C.J.B.; Westra, J. Assessment of Human Health and Environmental Risks of New Developments in Modern Biotechnology; RIVM Letter Report 2018-0089; National Institute for Public Health and the Environment: Utrecht, The Netherlands, 2018; 85p. [CrossRef]

195. Scheepmaker, J.W.A.; Hogervorst, P.A.M.; Glandorf, D.C.M. Future Introductions of Genetically Modified Microbial Biocontrol Agents in the Eu: Are Current eu Legislation and Risk Assessment Fit for Purpose? RIVM Letter Report 2016-0057; National Institute for Public Health and the Environment: Utrecht, The Netherlands, 2016. 